\title{
Structural Organization and Tectono-Metamorphic Evolution of the Pan-African Suture Zone: Case of the Kabye and Kpaza Massifs in the Dahomeyide Orogen in Northern Togo (West Africa)
}

\author{
M. S. Tairou ${ }^{1 *}$, Pascal Affaton ${ }^{2}$ \\ ${ }^{1}$ Department of Geology, Faculty of Sciences, University of Lome, Lome, Togo \\ ${ }^{2}$ Aix-Marseille University, CNRS, IRD, CEREGE, Mediterranean Europole of Arbois, Aix-en-Provence, France \\ Email: *msanitairou@yahoo.fr
}

Received October 2, 2012; revised November 6, 2012; accepted December 6, 2012

\begin{abstract}
The Kabye and Kpaza Massifs correspond to two main granulitic suites in the suture zone of the Pan-African Dahomeyide orogenic belt, in northern Togo. The Kabye Massif is composed of an important west verging nappe pile subdivided into two petrographic units. The nappes in its western petrographic unit are made up of leucocratic garnetbearing granulites defined as the "Lassa-Soumdina Granulites" (GLS). The eastern petrographic unit consists of melanocratic granulites, with metagabbroic structures, called the "Ketao-Sirka Granulites" (GKS). These two petrographic units are separated by the Panalo Mylonitic Zone (ZMP). This major west verging zone includes a syn-Dn +2 dextral shear contact. The Kpaza Massif comprises nappes of melanocratic granulites (GKM), comparable to the GKS of the Kabye Massif. All these granulitic nappes include boudins of pyroxenites or meta-anorthosites, and ultramafic rocks represented by serpentinites, talcschists, actinolite- and chlorite-schists which generally mark thrust soles. The GLS nappes are thrust over the Kara-Niamtougou orthogneissic unit (UKN) which is considered as the easternmost structural unit of the Dahomeyide external zone. On the other hand, the GKS nappes underlie those of the Binah meta-volcano sedimentary Complex (CB) which belongs to the Dahomeyide internal zone. As regards the Kpaza Massif, it occurs as a geologic window tectonically enclosed in the Mono Complex nappes (CM) corresponding to the southern part of the CB. The organization of the Kabye and Kpaza Massifs, as west verging nappe piles, and their relationships with the surrounding structural units express the tangential and folding tectonics that structured the Pan-African belt in northern Togo. The microstructures and mineral parageneses of the granulites and associated rocks in these two massifs indicate a polyphase tectono-metamorphic evolution: a syn-Dn granulitization (collision phase); a syn-Dn +1 amphibolitization (obduction or tangential phase); and a syn- to post-Dn +2 greenschist facies retrogressive metamorphism (post-nappe folding phase).
\end{abstract}

Keywords: Togo; Pan-African; Dahomeyide; Suture Zone; Microstructures; Tectono-Metamorphic Evolution

\section{Introduction}

In the Pan-African Dahomeyide orogenic belt $[1,2]$, the granulitic, eclogitic or mafic to ultramafic Dérouvarou (Benin), Kabye-Kpaza, Djabatouré-Anié, Agou-Ahito (Togo) and Akuse or Shai (Ghana) Massifs constitute a submeridian series of mountains materializing the suture zone (Figure 1). In northern Togo, the Kabye Massif represents the most remarkable feature of these mountains while the Kpaza one is comparable to a mega tectonic boudin located in the southern prolongation of the former. These two massifs are represented, on the west-

*Corresponding author. ern border of the Benino-Nigerian peneplain, as major submeridian reliefs associated with a thick lateritic glacis. Like most of the rock suites of the suture zone, they are considered as ophiolite [3-7] or continental arc [8] type, highly metamorphosed metamagmatites.

Recently, the Kabye Massif underwent structural, petrological and geochronological investigations [2,8-12]. However, it should be noted that the northern massifs in the Dahomeyide suture zone (those located between Dérouvarou and Anié) remain relatively little known compared to their southern counterparts (Agou-Ahito and Akuse/Shai Massifs; [13-21]). Petrological and geochemical studies done one these rocks are incomplete. 


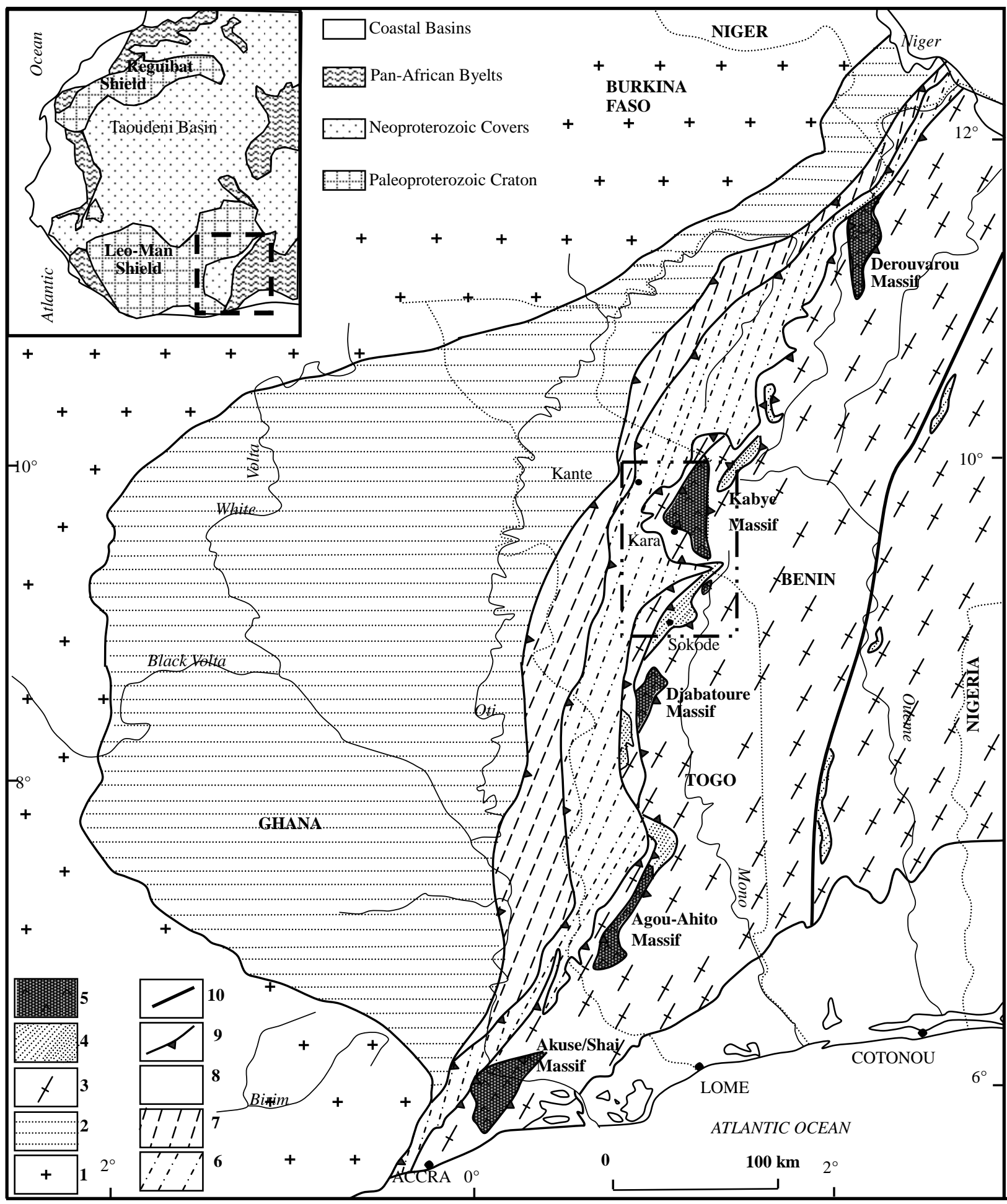

Figure 1. Schematic geological map showing the Volta Basin and the Benino-Togolese front of the Dahomeyide Belt. $1=\mathrm{Eb}$ urnean basement of the Leo-Man shield; 2 = Neoproterozoic cover of the Volta Basin; 3 = gneisso-migmatitic internal and external units; 4 = kyanite- and mica-bearing quartzites; 5 = basic and ultrabasic massifs of the suture zone; $6=$ Atacora Structural Unit; 7 = Buem Structural Unit; 8 = Meso-Cenozoic basin of the Guinea Gulf; $9=$ thrusting contact; $10=$ mylonitic zone of the Kandi Fault.

Moreover, these studies do not put sufficient emphasis on the Pan-African tectogenesis recorded in the components of these northern massifs. This is why the present paper intends to contribute to the petrostructural characteriza- 
tion of the Kabye and Kpaza Massifs. It defines the lithostructural organization of the two massifs and their relationships with the adjascent units. Furthermore, this paper determines the metamorphic parageneses of the main facies, in relation to the deformation micro-imprints, in other to retrace their tectono-metamorphic evolution.

\section{Regional Geological Context}

The southern part of the Transaharan mobile zone is represented by the Pan-African Dahomeyide orogenic belt [1]. This orogen overthrusts the Neoproterozoic cover constituting the eastern part of the Volta Basin or its Eburnean substratum of the Leo-Man shield [22-25]. This collisional belt consists of several lithostructural units composing its external, internal and suture zones (Figure 1).

The external zone corresponds to the Buem and Atacora structural units, representing the tectonized and metamorphosed part of the lower and middle mega-sequences of the Volta Basin, and the Kara-Niantougou, Mo and Amlame-Kpalime orhogneissic units [1,6,11,26, 27].

The Dahomeyide suture zone is materialized by the Dérouvarou (Benin), Kabye-Kpaza, Djabatouré-Anié, AgouAhito (Togo) and the Akuse or Shai (Ghana) Massifs. These massifs constitute a series of submeridian mountains mainly made up of granulitic or sometimes eclogitic and mafic to ultramfic rocks. This suture zone, therefore, includes rock types indicating Pan-African crustal thickening and comprising various granulites, pyroxenites and eclogitoids, associated with their heteromorphic equivalents and rare chromitites and metasediments [12,13,15, $18,20,21]$.

The Dahomeyide internal zone corresponds to the peneplain representing the Benino-Nigerian shield remobilized during the Pan-African events. It comprises polycyclic gneisso-migmatitic units, schist belts, Pan-African granitoids and Paleozoic molassic deposits [1-28].

In northern Togo, the Dahomeyide segment (Figure 2) corresponds to a series of west verging nappe and slice piles belonging to the external, suture and internal zones [6-11]. In this region, the Buem structural unit (USB) consists of anchi- to epizonal metasediments with cataclasis markers considered as typical of the classical Buem $[6,25]$. The Atacora structural unit (USA) comprises nappes made up of greenschist to amphibolite facies metasediments. These nappes are composed mainly of schists (USAs) or quartzites (USAq). External nappes representing a polycyclic basement are composed of orthogneisses, mainly in the Kara-Niamtougou (UKN) and Mo (UM) units, or amphibolites facies meta-volcanosediments, particularly in the Sokode-Kemeni (USK) and Mount Malfakassa (UMM) units. The Kabye and Kpaza Massifs consist of granulitic nappes of the suture zone (Figure 2). To the east of this zone, the Benino-Nigerian peneplain consists of the polycyclic basement internal nappes represented by the Binah (CB) and Mono (CM) gneissoamphibolitic complexes, and the orthogneissic Dompago (UOD) and the migmatitic Afem (UMA) units. In northern Togo, this peneplain is characterized by a scarcity of Pan-African granitoids and corresponds to the western margin of the Benino-Nigerian plate reworked during Pan-African times [1,29-31].

In the nappe piles of northern Togo, the Pan-African tectogenesis may be decomposed into five phases defined as Dn, Dn + 1, Dn + 2, Dn + 3 and Dn + 4 [1,11,32]. The Dn phase corresponds to the long process culminating in the collision between the active eastern margin, or the Benino-Nigerian plate, and the passive western margin belonging to the West-African Craton [2,33]. This collisional episode is materialized by a Sn foliation that is generally obliterated by the subsequent phases in the polycyclic basement and suture zone nappes. Indeed, the Dn +1 phase represents the main episode in Dahomeyide structuring leading to nappe and slice individualization and their west stacking $[6,11,34]$. This tangential phase is materialized by the $\mathrm{Sn}+1$ regional foliation and by a strong mineral or stretching $\mathrm{Ln}+1$ lineation. The postnappe episodes (Dn +2 to $\mathrm{Dn}+4)$ successively rework the $\mathrm{Sn}+1$ foliation. They result in centimetric to meteric $\mathrm{Pn}+2$ folds, with submeridian to NE-SW axes, hectormetric to kilometric Pn +3 antiforms and synforms, with NE-SW axes, and plurikilometric Pn +4 virgations, with NE-SW to ENE-WSW axes [11-32].

\section{Lithostructural Organization of the Kabye and Kpaza Massifs}

A synthetic analysis of satellite images and aerial photographs covering the northern Togo [11] and field data lead to define the lithostructural organization of the Kabye and Kpaza Massifs. They clarify the relationships between these massifs and the external and internal zones of the Dahomeyide.

\subsection{The Kabye Massif}

As a whole, the granulitic Kabye nappes are tectonically enclosed between the UKN orthogneisses and the internal gneisso-migmatitic units (Figure 3). These west verging granulitic nappes are demarcated by thrust corridors characterized by more or less retromorphosed ultramafic shreds or mylonitic amphibolites. These granulites belong to two main facies that are geographically well distributed (Figures 2 and 3): the more or less leucocratic garnet-bearing granulites, in the west, called the "LassaSoundina granulites" (GLS), and the melanocratic granulites with metagabbroic structures in the east, defined as 


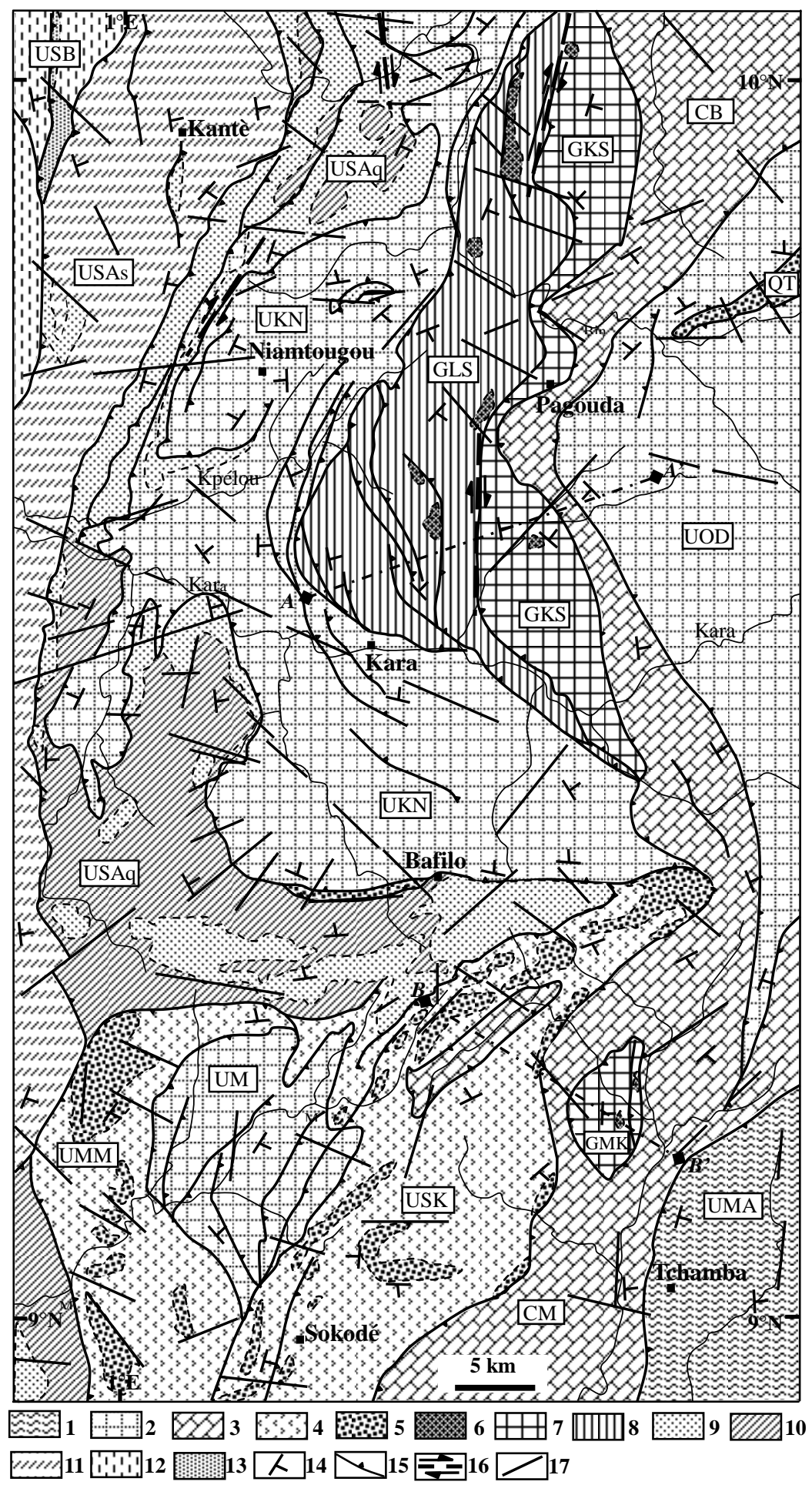

Figure 2. Lithostructural sketch showing the main geological suites in northern Togo. 1 = nappes of the Afem migmatitic unit (UMA); 2 = orthogneissic nappes of the Kara-Niamtougou (UKN), Mo (UM) and Dompago (UOD) units; $3=$ gneisso-amphibolitic nappes of the Binah (CB) or Mono (CM) Complex; 4 and 5 = nappes of micaschists, quartz-micaschists and kyanitebearing quartzites of the Sokode-Kemeni (USK) and Mount Malfakassa (UMM) units or Taneka kyanite-bearing quartzites (QT); 6, 7 and 8 = pyroxenite bodies, nappes of leucocratic Lassa-Soumdina (GLS) and melanocratic Ketao-Sirka (GKS) granulites of the Kabye and Kpaza Massifs; 9 and 10 = quartzite and micaschist nappes of the eastern Atacora subunit (USAq); 11 = schist nappes of the western Atacora subunit (USAs); 12 and $13=$ schists and quartzitic sandstones or metasilexites of the Buem structural unit (USB); 14 = main foliation plane (S1 or Sn + 1); 15 = thrust contact; 16 = shear corridor; 17 = fracture. A-A', B-B' = location of synthetic cross-sections Figures 3 and 7. 
the "Ketao-Sirka granulites" (GKS). These two petrographic units are also morphostructural: the GLS correspond to the main reliefs of Mount Kabye and the GKS define the eastern margin largely masked by a thick lateritic glacis. They are separated by a tectonic contact materialized by the Panalo mylonitic zone (ZMP). Based on the metamorphic peak of the frontal granulites, Sabi [12] proposed to subdivide the GLS into two overthrusting sub-units.

\subsubsection{The Western Granulitic Unit Nappes (GLS) and Their Relationships with the Kara-Niamtougou Orthogneissic Unit (UKN).}

The western nappes of the Kabye Massif consist of little varied leucocratic garnet-bearing granulites (GLS), with shreds of pyroxenites, amphibolo-pyroxenites and metasedimentary rocks (Figure 3). These granulites are generally greyish, and sometimes reddish, with garnetiferous facies or true garnetites. The garnet crystals are millimetric to centimetric and probably of several generations. Their great abundance is the outstanding characteristic of the GLS. These granulites have a foliated or augen structure. They show fine sheets and felsic boudins alternating with amphibole- and pyroxene-bearing lenses, with a homogeneous distribution of small garnet crystals. In places, a thickening of the dark sheets indicates transposition of centimetric amphibolo-pyroxenite boudins into the main Sn +1 foliation. There are truly ribbon rocks made up of alternating centimetric reddish brown and melanocratic sheets. This banding is generally discordant relative to the main $\mathrm{Sn}+1$ foliation and suggests an earlier magmatitic differentiation. Sometimes, true migmatitic facies are observed with decimetric amphibole-pyroxenite xenoliths (Figure 4(a)) showing internal foliation (Sn), prior to $\mathrm{Sn}+1$. In places, metric to decametric lenses, corresponding to pinkish and mainly feldspathic granulite,

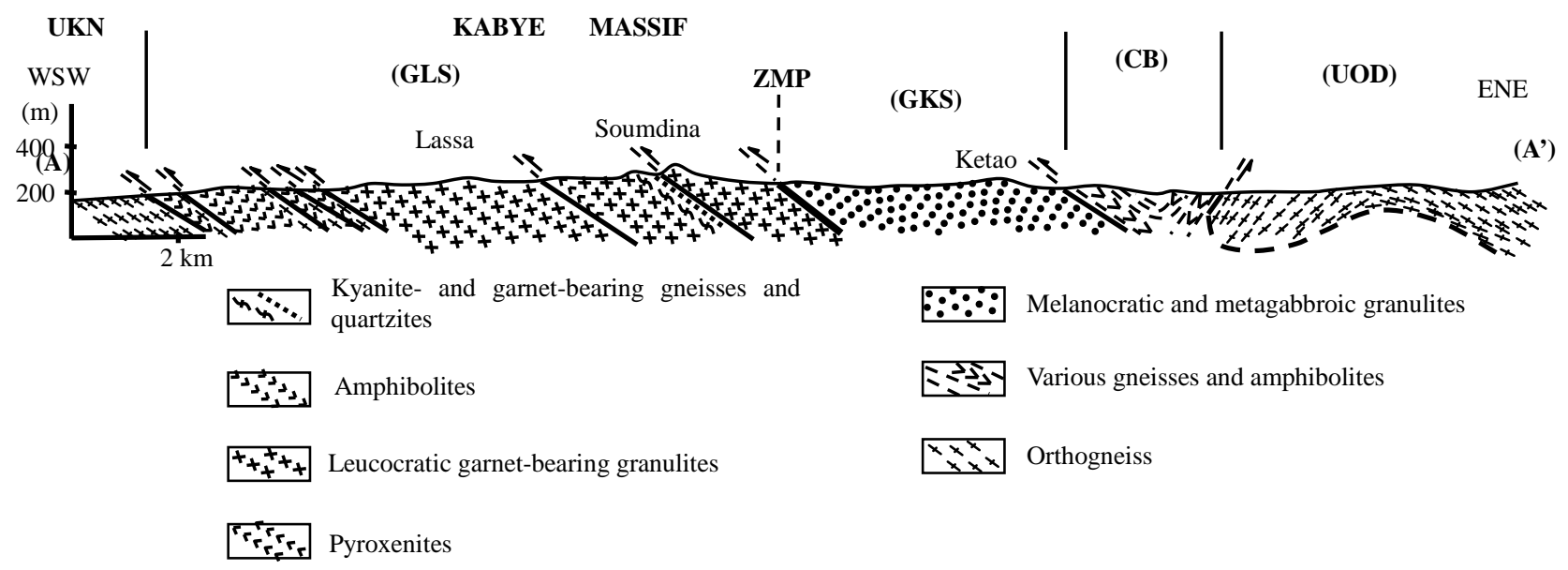

Figure 3. Synthetic cross-section showing the lithostructural organization of the Kabye Massif and its relationships with the adjascent structural units.

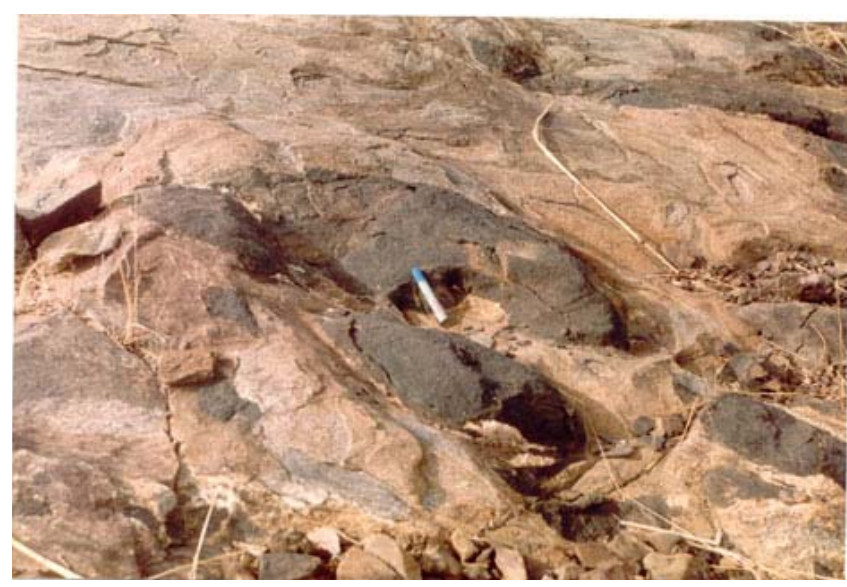

(a)

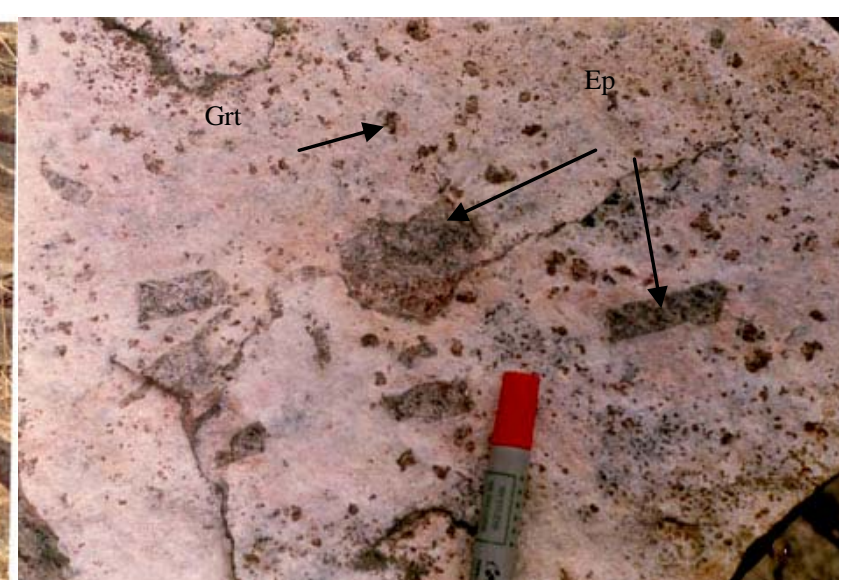

(b)

Figure 4. Distinctive characteristics of some outcrops of the Lassa-Soumdina granulites (GLS). (a) Amphibolitized pyroxenite xenolith in migmatitic granulite facies; (b) Pinkish garnet-bearing granulite (plagioclasic metacumulate) displaying post-tectonic and prismatic epidote crystals in the main $\mathrm{Sn}+1$ foliation plane. 
contain post-tectonic prismatic epidote crystals (Figure 4(b)). They are considered as former cumulative anorthosites.

The metric to hectometric ultramafite shreds, associated with the GLS, are represented by pyroxenites or various amphibolo-pyroxenites, with meta-cumulate structures, and sometimes metagabbros or chromitites. These rocks, associated with talcschists, serpentinites, and actinolite- and chlorite-schists, are often involved in nappe contacts. Decametric to hectometric lenses of metasedimentary rocks constitute lenticular layers of megaboudins along the length of the massif [7-12]. They correspond to kyanite- and garnet-bearing gneisses and quart- zites. The metasedimentary nature of these rocks and their kyanite-bearing paragenesis lead to consider them as equivalents of the silico-aluminous sediments that are coeval with the granulite protoliths. Finally, garnet-bearing amphibolites representing retromorphosed granulites, are generally found in the Kabye Massif thrust front, above the UKN (Figure 3).

The main cleavage plane of the garnet-bearing granulites corresponds to the regional Sn +1 foliation, striking SE-NW to SSE-NNW or NE-SW, with low to medium dips to East (Figure 5). In places, the $\mathrm{Sn}+1$ foliation corresponds to the transposition of an earlier Sn plane. Generally, the $\mathrm{Sn}+1$ plane bears a highly scattered min-

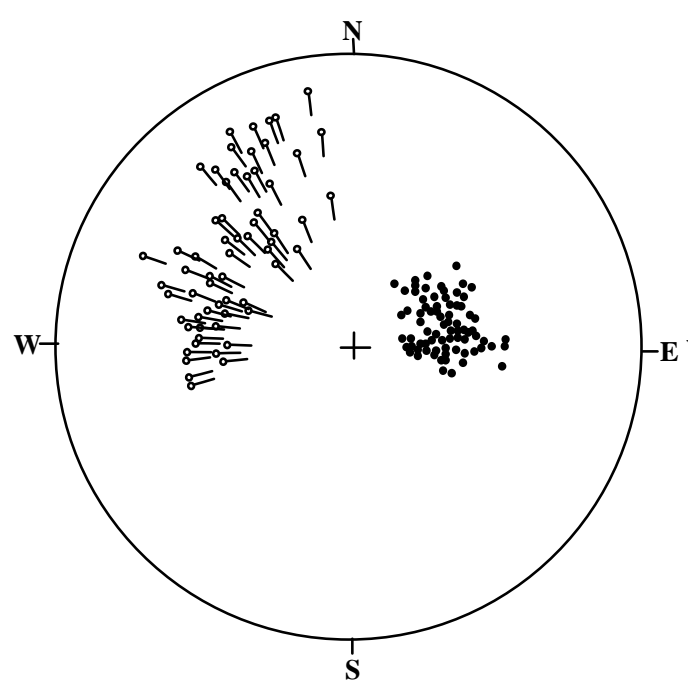

(a)

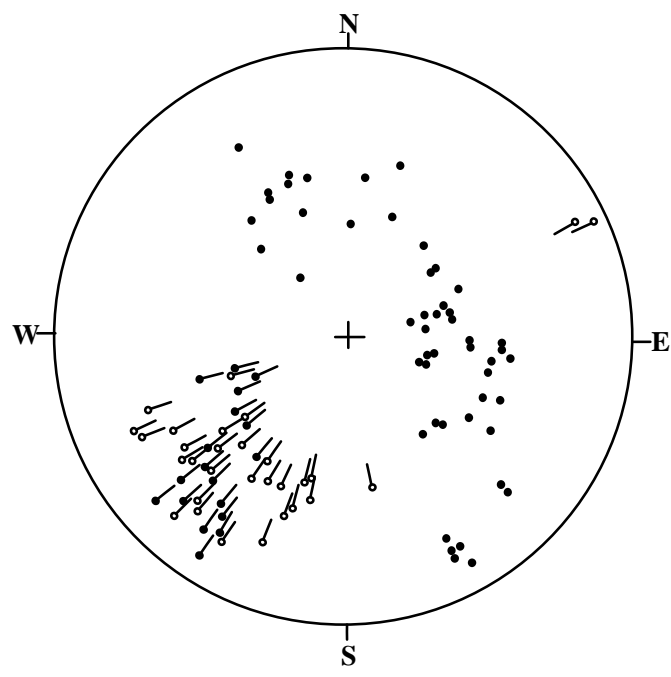

(c)

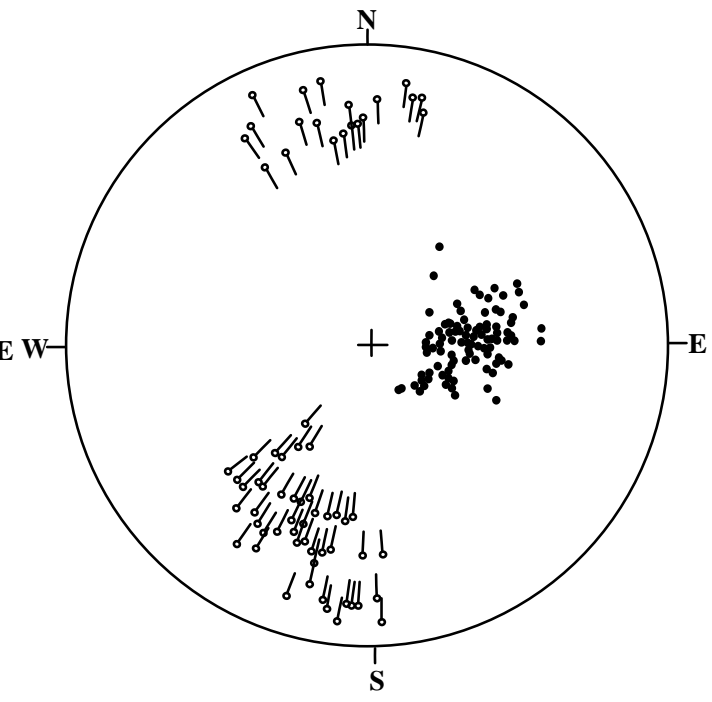

(b)

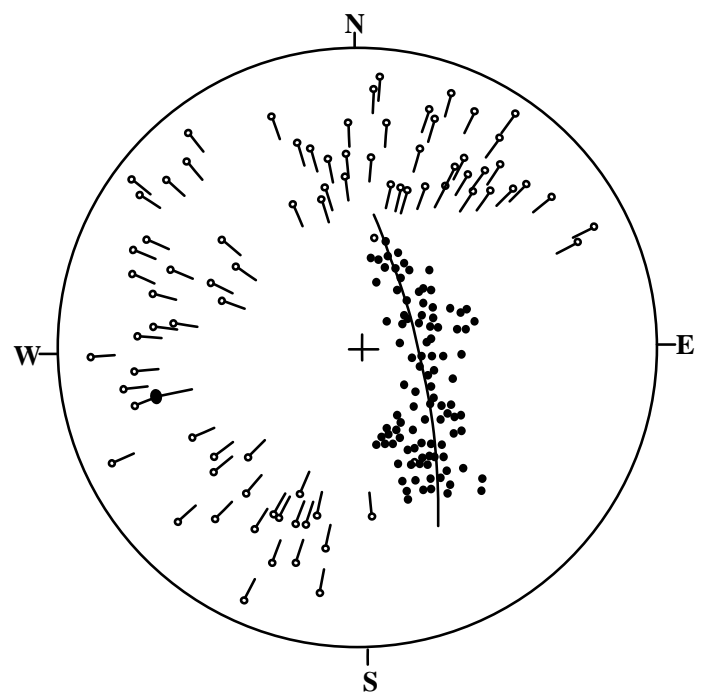

(d)

$$
\text { - } 1 \text { o } 2 \multimap 3 \circ 4
$$

Figure 5. Synthetic stereograms of the structural elements observed in the Kabye Massif granulites in the Lassa (a), Soumdina (b), Tchitchao (c) and Pagouda (d) areas. 1 = pole of $\mathrm{Sn}+1$ foliation plane; 2 = pole of $\mathrm{Ln}+1$ mineral or stretching lineation; 3 = pole of $\mathrm{Pn}+2$ axis; 4 = pole of constructed $\mathrm{Pn}+4$ axis (projection using upper hemisphere). 
eral or stretching Ln +1 lineation (Figure 5). This scattering is related to posterior folding phases that are not generally well represented in the granulites. These folding episodes are materialized by decimetric to metric Pn +2 folds, with NE-SW axes (Figure 5(c)), and cartographic $\mathrm{Pn}+3$ and $\mathrm{Pn}+4$ structures, with SW-NE to WSW-ENE axes (Figure 5(d)). As in the Atacora quartzites (USAq), fractures are well represented in the granulites [32-35]. They correspond to a dense multidirec- tional network resulting from four generations of PanAfrican paleostresses.

The morphostructural contrast between the western orthogneissic peneplain (developed on the UKN, in the external zone) and the Kabye Massif front underscores the major thrusting of this massif over the UKN. This overthrust is particularly clear at the scale of satellite images and aerial photographs (Figure 6). It is materialized by amphibolites and talcschist or serpentinite shreds which

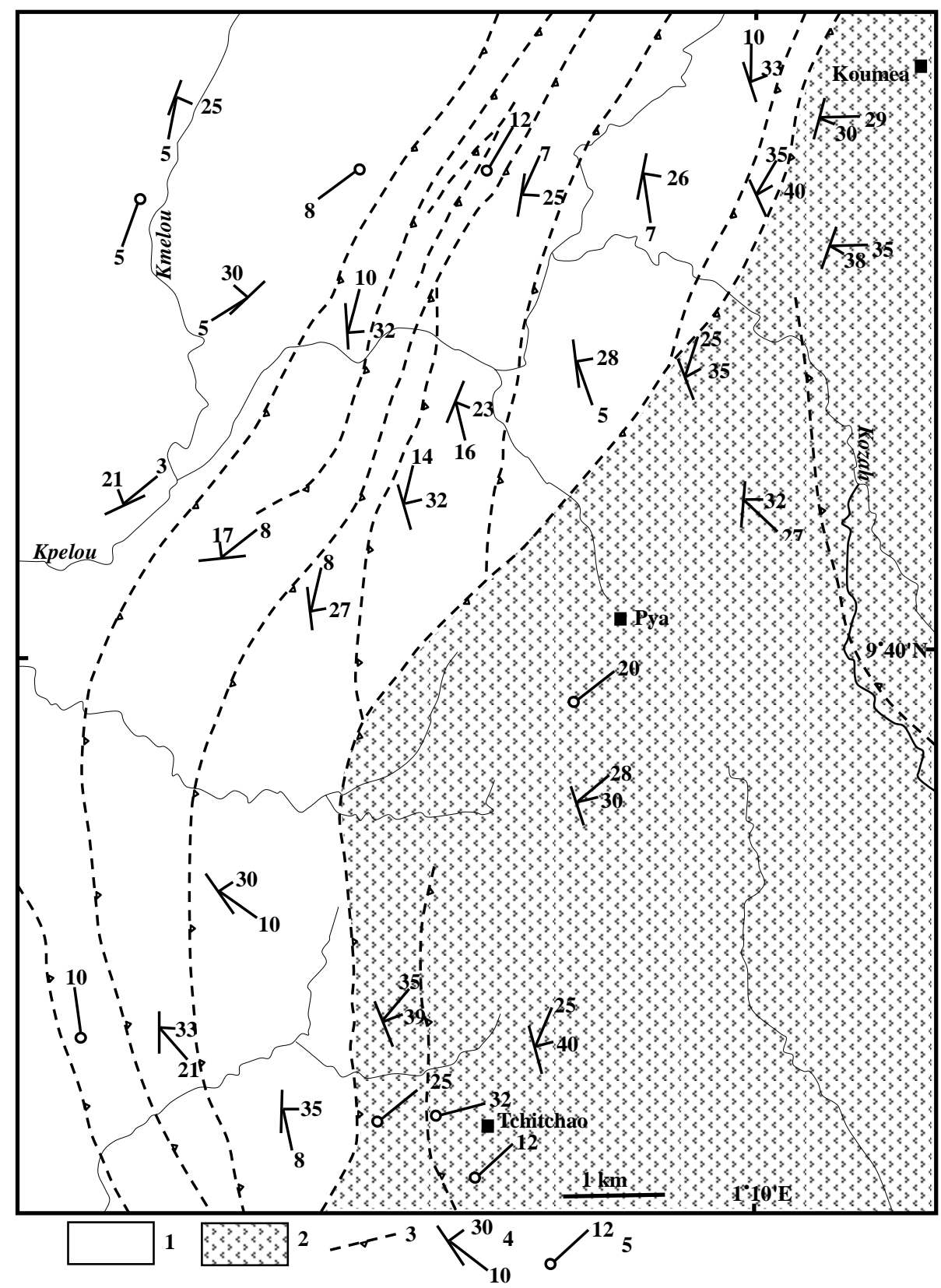

Figure 6. Lithostructural sketch displaying the thrust relationships between the western front of the Kabye Massif and the eastern nappes and slices of the orthogneissic Kara-Niamtougou unit (UKN) in the Tchitchao-Kouméa area (according to [11]); 1 = generally mylonitic orthogneiss and phyllonites of the UKN; $2=$ Kabye Massif leucocratic and garnet-bearing granulites; 3 = thrust contact; 4 = Sn +1 foliation plane (strike and dip) with $\mathrm{Ln}+1$ lineation (strike and plunge); $5=$ Pn +2 axis (strike and plunge). 
overlie phyllonites and orthogneissic mylonites. The synthetic cross-section (Figure 3) shows one aspect of the complexity of this overthrust characterized by a tectonic melange including decimetric to hectometric slices of orthogneisses, granulites and amphibolites. This complexity suggests a late and multiple scaling associated with this major thrust plane. In the Tchitchao-Koumea area (Figure 6), structural analysis defines an average thrust plane with a $30^{\circ}$ dip to East [11]. Moreover, the cartographic relationships between the granulitic (GLS) and orthogneissic (UKN) nappes suggest that the overthrust of the Kabye Massif postdates the emplacement of UKN nappe pile or of the entire Dahomeyide external zone.

\subsubsection{The Eastern Granulitic Unit Nappes (GKS) and Their Relationships with the Internal Zone Units}

The eastern nappes of the Kabye Massif consist of melanocratic granulites (GKS), with metagabbroic structures. These rocks are relatively homogeneous, clearly foliated, with alternating feldspathic and pyroxeno-amphibolitic sheets. Their outcrops sometimes contain thin felsic amphibole- and garnet-bearing lodes and veinlets. These granulites are associated with shreds of metacumulates represented by coarse pyroxenites with centimetric crystals.

The mylonites and ultramylonites resulting from these granulites (GKS) are very representative of the Panalo mylonitic zone (ZMP). They show progressive westward crushing leading to a felsic facies including pyroxene or amphibole porphyroblasts. Sometimes, they show a NNESSW dextral shear plane (C) intersecting the NNW-SSE Sn +1 foliation. This C plane defines a syn-Dn +2 shear corridor within the ZMP (Figure 2). In places, the Sn + 1 foliation in the GKS is submeridian to SE-NW or NE$\mathrm{SW}$. It shows a mineral or stretching $\mathrm{Ln}+1$ lineation that is generally submeridian. Geometric variations of the $\mathrm{Sn}$ +1 plane result from post-nappe folding episodes that structurally complicate the relationships between the eastern nappes of the Kabye Massif and the western nappes of the internal zone. For ex- ample, at the latitude of Ketao, the structural relation- ships between the different units express well the history of the overthrusting nappes that are refolded by Dn +2 , Dn +3 and Dn +4 (Figure 3; $[11,12])$. Thus, the Binah complex (CB), overthrusting the Kabye Massif, and the Dompago orthogneissic unit (UOD) which overthrust the $\mathrm{CB}$, are involved in the kilometric $\mathrm{Pn}+3$ folds (Figures 2 and $\mathbf{3}$ ).

\subsection{The Kpaza Massif}

The Kpaza Massif is constituted by granulites comparable to those of the eastern unit of the Kabye Massif (GKS). These melanocratic granulites are defined as the "Kpaza Massif granulites” (GKM). They are massive or little foliated, with metagabbroic structures and lenticular pyroxeno-amphibolitic porphyroblasts defining a clear stretching Ln +1 lineation. Their outcrops include small pegmatitic lodes (with feldspar, amphibole, and biotite) and metric pyroxenitic shreds, with metacumulate structures.

In the GKM, the $S n+1$ foliation is not well developed and has, like the $\mathrm{Ln}+1$ lineation, a submeridian strike. The Kpaza Massif is composed of at least two west verging nappes (Figure 7) that are tectonically enclosed by the Mono complex (CM). The thrust sole of its western nappe is materialized by mylonitic granulites, feldspathic

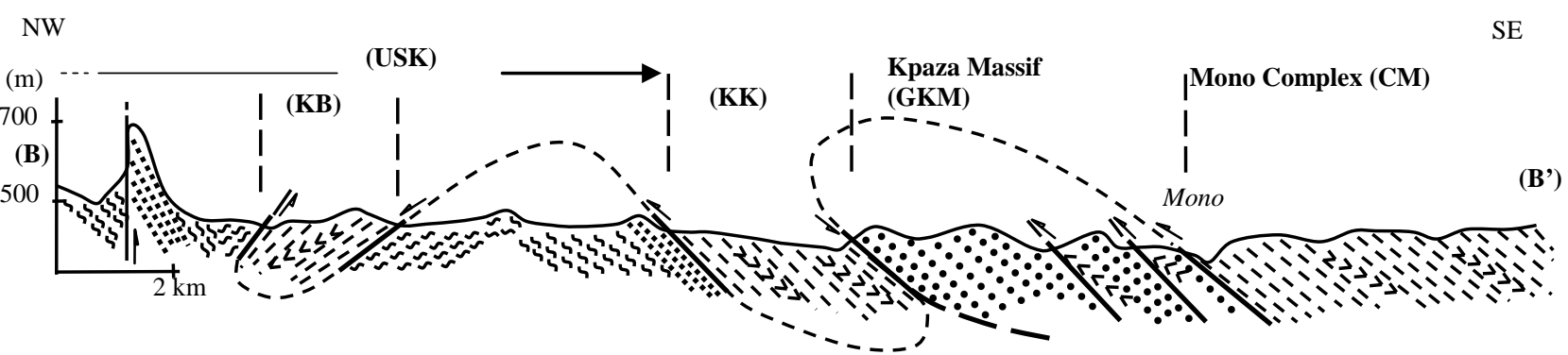

Two micas- and garnet-bearing quartz micaschists and micaschists, and kyanite-bearing quartzites of the
Sokode-Kemeni unit (USK)

$\because \because \because$ Melanocratic and metagabbroic granulites, with pyroxenitic shreds (GKM)

Various gneisses and amphibolites composing the Mono Complex (CM) and its western Kpaza (KK) and הouzena (KB) klippes

Figure 7. Synthetic cross-section defining the structural relationships between the Kpaza Massif nappes and their enclosing units 
amphibolites and gneisso-amphibolitic magmatites. Moreover, the western part of the CM nappes is represented as klippes (KK and $\mathrm{KB}$ ) that correspond to $\mathrm{Pn}+3$ synforms (Figure 7). This suggests that the Kpaza Massif, underlying the CM eastern nappes, overthrusts the SokodeKemeni unit (USK) at the end of the Dn +1 tangential phase.

\section{Microstructures and Tectono-Metamorphic Evolution}

Micro-imprints of the Pan-African deformation are clear in the different granulites of the Kabye and Kpaza Massifs. An analysis of deformation-crystallization relationships in several thin sections, based on the criteria established by several authors [36-39], defines the mineral parageneses associated in the granulites. This reconstructtion retraces the Pan-African tectono-metamorphic evolution of the Kabye and Kpaza Massifs components.

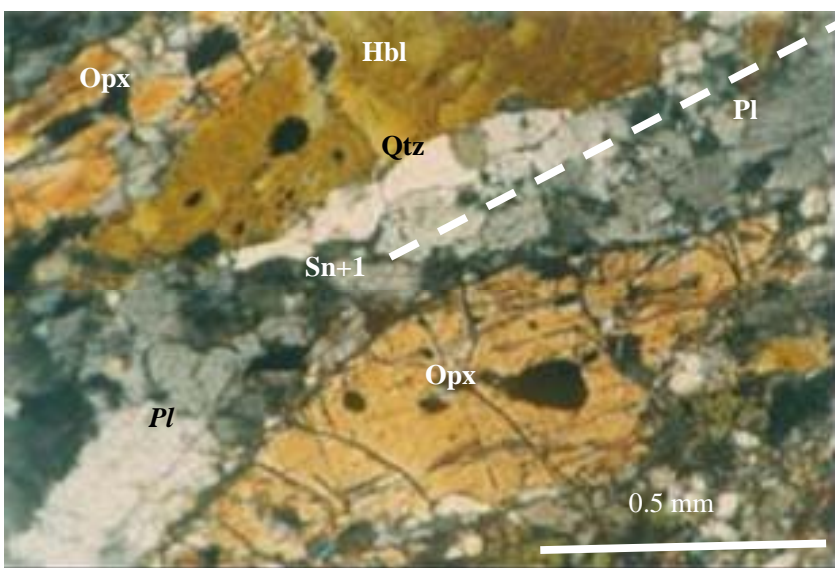

(a)

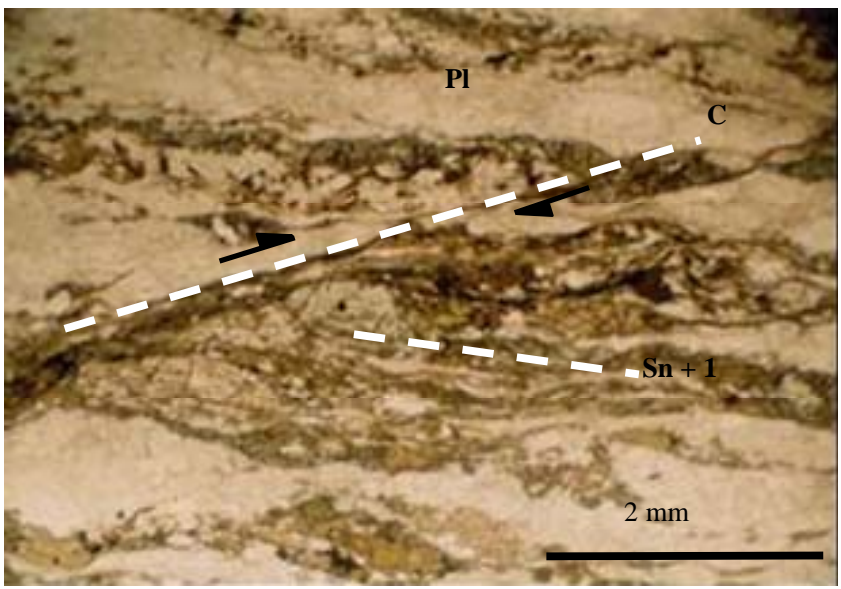

(c)

\subsection{Microstructural Characteristics and Metamorphic Evolution of the Melanocratic Granulites}

The melanocratic and metagabbroic granulites (GKS and GKM) of the Kabye and Kpaza Massifs are generally porphyroblastic, with pyroxene and plagioclase blasts wrapped in a more or less oriented granoblastic groundmass. Clearly oriented textures are found particularly in the GKS. In these granulites, pyroxene porphyroblasts (Opx and Cpx) are represented as micro-boudins in the main foliation (Sn $+1 / / \mathrm{Sn})$. They are more or less retromorphosed into hornblende (Figure 8(a)). Their lenticular appearance, the widespread distortion of their cleavages, and the intracrystalline fractures suggest that they result from an ante-Dn +1 recrystallization phase. Indeed, it is clear that these pyroxene porphyroblasts indicate a syn-Dn recrystallization. Their large rim of green hornblende characterizes the syn-Dn +1 retromorphic stage.

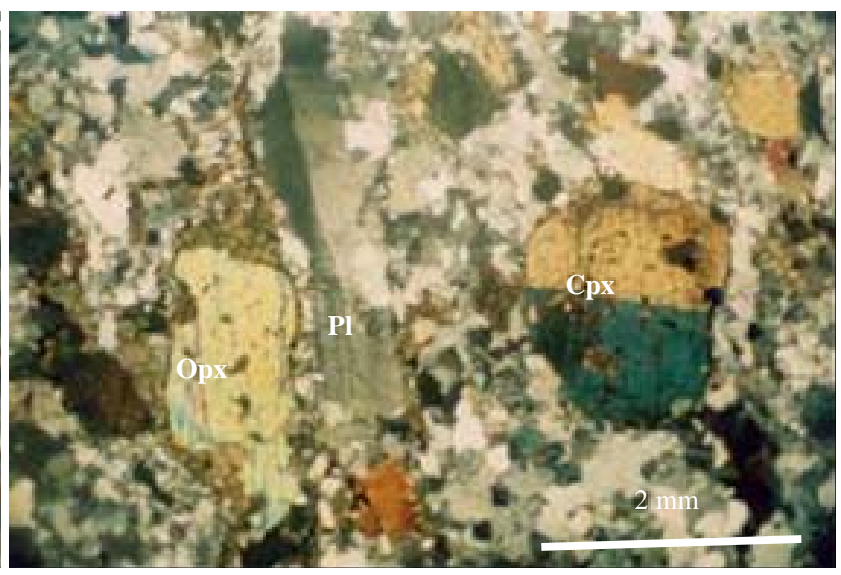

(b)

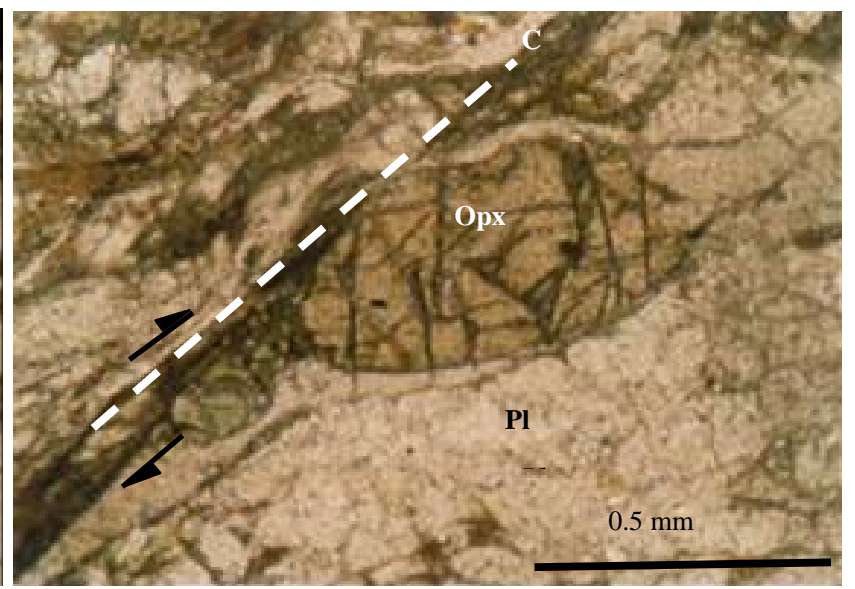

(d)

Figure 8. Some microstructures in melanocratic and metagabbroic granulites from the Kabye and Kpaza Massifs; (a) Oriented texture in Ketao-Sirka granulites (GKS), with lenticular hypersthene porphyroblasts; (b) Slightly oriented texture in the Kpaza Massif granulites (GKM), with augite, hypersthene and ante-Dn plagioclase porphyroblasts; (c) Dextral shear structures characterizing the Panalo mylonitic zone (ZMP) facies; (d) Detail of shear plane displaying a hypersthene porphyroblast with a pressure fringe. 
The ante-Dn porphyroblasts are particularly evident in the GKM. They are made up of ante-tectonic or ante-Dn pyroxenes (augite and hypersthene) wrapped in a more or less oriented feldspathic matrix (Figure 8(b)).

The GKS and GKM include at least two generations of plagioclase:

1) gray and more or less porphyroblastic sections, with microfractures, flexured polysynthetic twins and undulatory extinction, belong to the ante- and syn-Dn recrystallization stages; such sections (remarkably tectonized and underlining the Sn foliation) are more frequent in the GKM (Figure 8(b));

2) generally limpid sections, sometimes associated with quartz and materializing the $\mathrm{Sn}+1$ foliation, are considered as syn-Dn +1 plagioclases.

Syn-Dn +1 green hornblende is well represented in the main $\mathrm{Sn}+1$ foliation and defines the $\mathrm{Ln}+1$ mineral lineation. Accessory constituents of the GKS and GKM are ilmenite and retromorphic minerals (biotite, actinolite, sphene, chlorite, magnetite, epidote) associated with green hornblende. These minerals are particularly abundant in the feldspathic amphibolites, enclosing porphyroblastic green hornblende, that sometimes display an internal schistosity $(\mathrm{Si}=\mathrm{Sn})$. This internal schistosity is slightly oblique to the external one $(\mathrm{Se}=\mathrm{Sn}+1)$. Rare ante- to post-Dn +1 garnet sections are almost entirely pseudomorphosed into chlorite. This appears in bands, clusters or sheaf-like structures. In places, post-tectonic mineral association (actinolite-chlorite-epidote) express a rough $\mathrm{Sn}+2$ foliation, oblique to $\mathrm{Sn}+1$.

$\mathrm{S} / \mathrm{C}$ type structures are frequent in the ZMP mylonites. The millimetric pyroxenes (Opx and Cpx) are caught up in the $\mathrm{Sn}+1$ foliation which is subparallel to Sn and intersected by the $\mathrm{C}$ dextral shear planes (Figures 8(c) and (d)). The plagioclasic porphyroblasts are also highly deformed. Fine epidote crystals and serpentine or oxide (magnetite) clusters mark these shear planes. The ultramylonites show a serpentinous or chloritic actinolite- and epidote-bearing groundmass, with $\mathrm{Pn}+2$ microfolds and microblasts of plagioclase, ante- to syn-Dn +1 garnet and hornblende.

The pyroxenites are porphyroblastic and include millimetric blasts $(>5 \mathrm{~mm})$ of green hornblende, with pyroxene inclusions, and pyroxene (Opx + Cpx)- and plagioclase-bearing equant groundmass. Apart from cleavage distortions and slightly undulatory extinction in pyroxene sections (ante-tectonic crystals), these more or less amphibolitized pyroxenic metacumulates do not display any plane indicating a particular deformation stage.

The microstructures observed in the melanocratic granulites, in their amphibolitic, mylonitic or ultra mylonitic equivalents, and in the pyroxenites retrace three major tectonic phases (Dn, Dn +1 and $\mathrm{Dn}+2$ ) materialized by the $\mathrm{Sn}, \mathrm{Sn}+1$ and $\mathrm{Sn}+2$ foliations. $\mathrm{Sn}$ and $\mathrm{Sn}+1$ are more evident than the $\mathrm{Sn}+2$ foliation. The latter remains very crude and appears mainly in the well retromorphosed facies. The $\mathrm{C}$ dextral shear plane, described in the ZMP mylonites, probably results from the $\mathrm{Dn}+2$ phase.

The Sn foliation is materialized by Opx $+\mathrm{Cpx}+\mathrm{Pl}+$ $\mathrm{Ilm} \pm$ Qtz paragenesis that defines a first granulite facies metamorphim. This foliation is clearly transposed in the main Sn +1 plane corresponding to an amphibolite facies $(\mathrm{Hbl}+\mathrm{Pl}+\mathrm{Qtz}+\mathrm{Grt})$ retrograde paragenesis. In the amphibolites and ultramylonites, the $\mathrm{Dn}+2$ phase is associated with a more advanced greenschist facies paragenesis $(\mathrm{Ep}+\mathrm{Act}+\mathrm{Chl}+\mathrm{Srp}+\mathrm{Mag})$ underlining the crude Sn + 2 foliation.

These syn-Dn, syn-Dn +1 and syn- to post-Dn +2 parageneses characterize the GKS and GKM metamorphic evolution (Table 1). Moreover, a relict paragenesis, represented by ante-Dn pyroxenes (Opx + Cpx) and plagioclase porphyroblasts, coexists mainly in the GKM (Figure 8(b)). Most of the pyroxenic metacumulate crystals are considered as representative of this ante-Dn paragenesis. Therefore, they are relicts of magmatic protoliths or an ante-Dn metamorphic paragenesis supposed to be eclogitic [2].

\subsection{Microstructural Characteristics and Metamorphic Evolution of the Kabye Massif Leucocratic Granulites}

Most of the petrographic components of the Kabye Massif western nappes are leucocratic granulites (GLS). In these rocks, the porphyroblasts are represented by millimetric sections of garnet, pyroxene or kyanite in a clearly oriented granoblastic to granonematoblastic groundmass (Figures 9(a1) and (a2)).

The main facies of the GLS, represented by garnetbearing granulites, include lenticular Cpx (augite + diopside) and Opx (hypersthene) porphyroblasts. These minerals display deformed cleavages, microfractures, undulose extinction and large rims or overgrowths of green hornblende (Figure 9(a3)). The porphyroblasts are surrounded by the main $\mathrm{Sn}+1$ foliation and belong to a prior Sn foliation. As in the melanocratic granulites (GKS and GKM), ante-Dn porphyroblasts coexist. Moreover, microfabrics with Cpx rims around the Opx suggest two granulitization stages.

Plagioclase and quartz constitute the leucocratic and granoblastic groundmass in these granulites. Two generations of polygonal plagioclase sections can be defined:

1 ) the first is represented mainly by syn-Dn sections, with triple junctions, undulatory extinction and flexural twins;

2) the second is a syn-Dn +1 type and belongs to lenses expressing the $\mathrm{Sn}+1$ foliation.

Furthermore, pinkish garnet- and epidote-bearing granulites or meta-anorthosites enclose ante-Dn plagioclase 
porphyroblasts. These porphyroblasts display polysynthetic flexural twins and a spectacularly abnormal extinction (Figure 9(a4)).

Two quartz generations coexist in the GLS various granulites. They are syn-Dn and syn-Dn +1 , as plagioclases, and differ in size, form and optical properties. On the contrary, only one generation of green hornblende dominates in the melanocratic sheets of the granulites. It clearly corresponds to a syn-Dn +1 retromorphic recrystallization.
The garnet porphyroblasts vary much in shape and size. They are generally surrounded by the $\mathrm{Sn}+1$ foliation. Their highly deformed appearance is related to the multiple posterior tectonic phases. According to their shape, their relationships with $\mathrm{Sn}$ and $\mathrm{Sn}+1$ foliations, and their inclusions, at least three generations of garnet can be defined. The first garnets are the most abundant, anteDn +1 type, most deformed and surrounded by the $\mathrm{Sn}+$ 1 foliation (Figure 9(a1)). In detail, it is difficult to dis-

Table 1. Synthesis of crystallization-deformation relationships and characteristic parageneses of the tectono-metamorphic evolution of the Kabye and Kpaza Massifs melanocratic and metagabbroic granulites (GKS and GKM). The mineral symbols are due to [40].

\begin{tabular}{|c|c|c|c|c|c|c|c|}
\hline Deformation & & Dn & & $\mathrm{Dn}+1$ & & $\mathrm{Dn}+2$ & \\
\hline Marks & & Sn & & $\mathrm{Sn}+1$ & & $n+2 / S n+2 /$ & \\
\hline Minerals & Ante-Dn & Syn-Dn & Post-Dn Ante-Dn + 1 & Syn-Dn +1 & Post-Dn + 1 Ante-Dn + 2 & Syn-Dn +2 & Post-Dn +2 \\
\hline Сpx & $\mathrm{xxxxx}$ & xxxxxxxx & & & & & \\
\hline Opx & $\operatorname{xxxxx}$ & $\operatorname{xxxxxxxx}$ & & & & & \\
\hline $\mathrm{Pl}$ & $\mathrm{xxxxx}$ & xxxxxxxx & & xxxxxxxx & & & \\
\hline $\mathrm{Hbl}$ & & & & xxxxxxxx & & & \\
\hline Qtz & & $\operatorname{xxxxxxxx}$ & & $\operatorname{xxxxxxxx}$ & & & \\
\hline Ilm & & xxxxxxxx & & & & & \\
\hline $\mathrm{Bt}$ & & & & & & $\operatorname{xxxxxxxx}$ & $\operatorname{xxxxxxxx}$ \\
\hline Grt & & & $\mathrm{xxx}$ & xxxxxxxx & xxxxxxxx & & \\
\hline Mag & & & & & & & Xxxxxxxx \\
\hline Еp & & & & & & $\mathrm{xxxx}$ & $\operatorname{xxxxxxxx}$ \\
\hline Act & & & & & & $\operatorname{xxxxxxxx}$ & $\operatorname{xxxxxxxx}$ \\
\hline Chl & & & & & & $\operatorname{xxxx}$ & $\operatorname{xxxxxxxx}$ \\
\hline Sph & & & & & & & $\operatorname{xxxxxxxx}$ \\
\hline Srp & & & & & & $\operatorname{xxxx}$ & $\operatorname{xxxxxxxx}$ \\
\hline Metamorphism & & \multicolumn{2}{|c|}{ Granulite facies } & \multicolumn{2}{|c|}{ Amphibolite facies } & \multicolumn{2}{|c|}{ Greenschist facies } \\
\hline
\end{tabular}

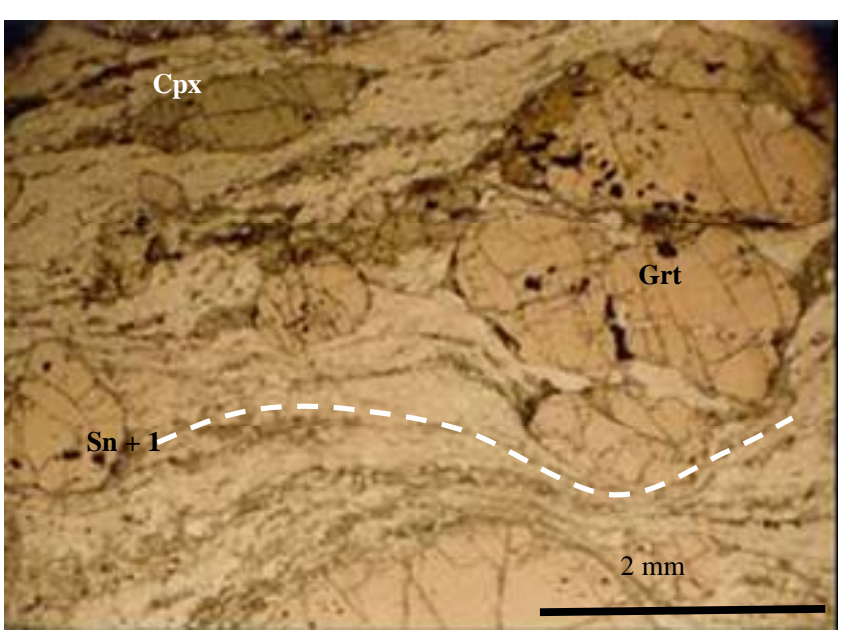

(a1)

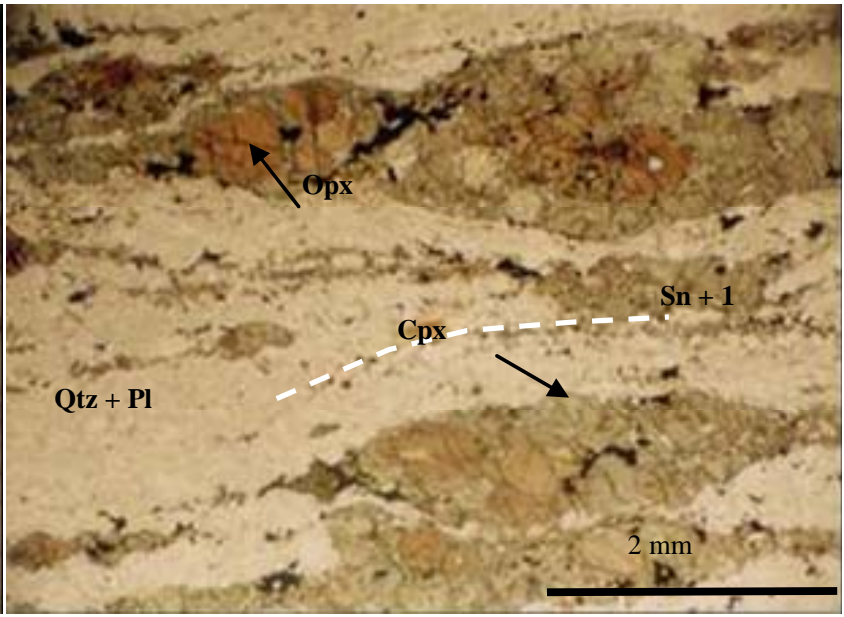

(a2) 


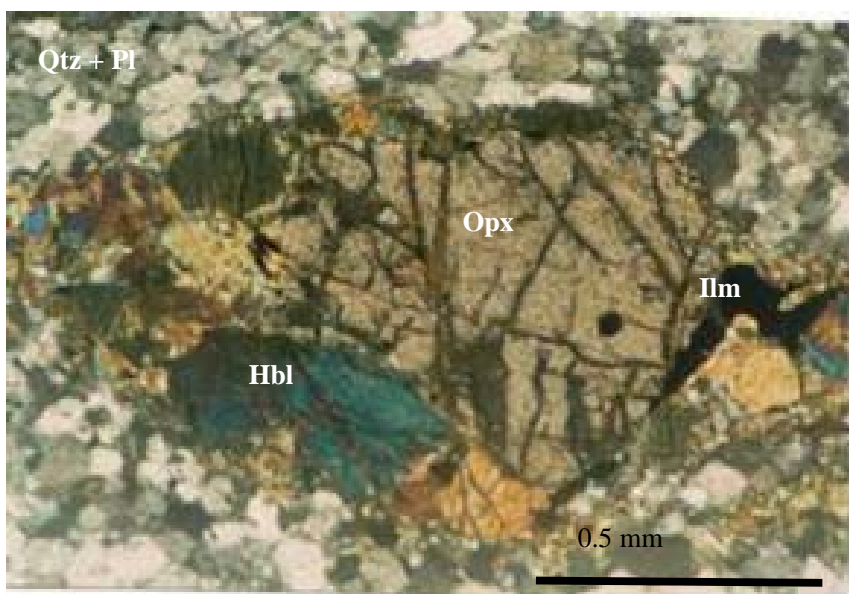

(a3)

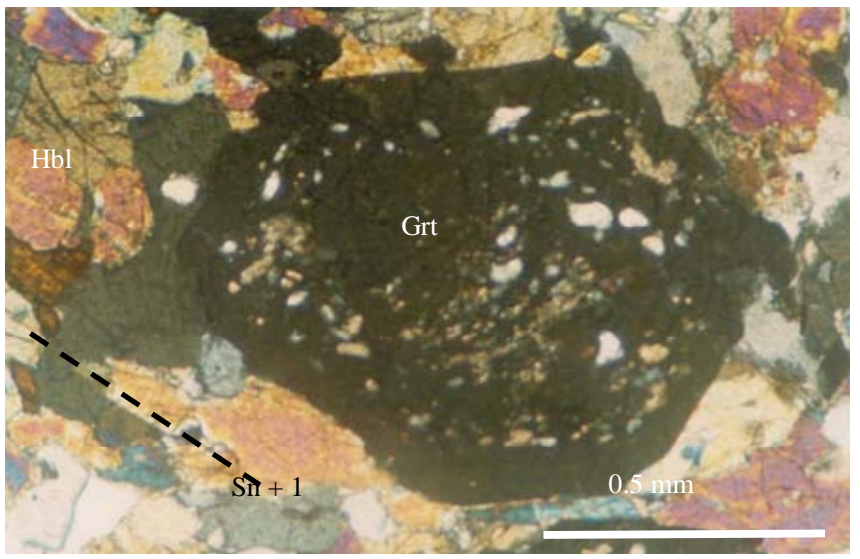

(b1)

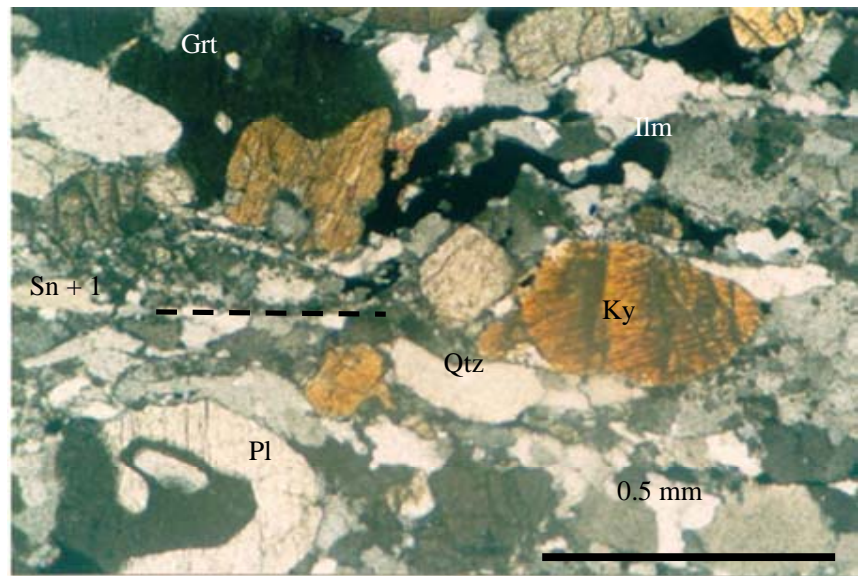

(b3)

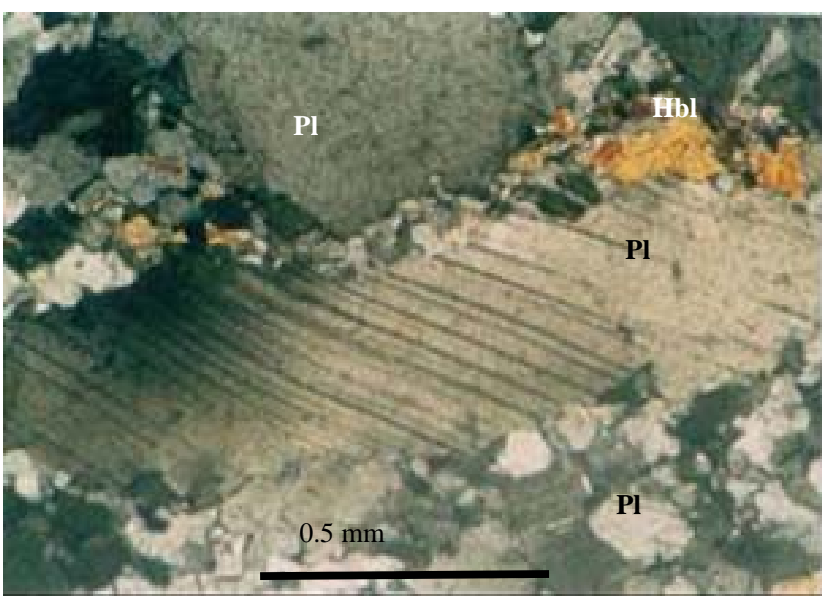

(a4)

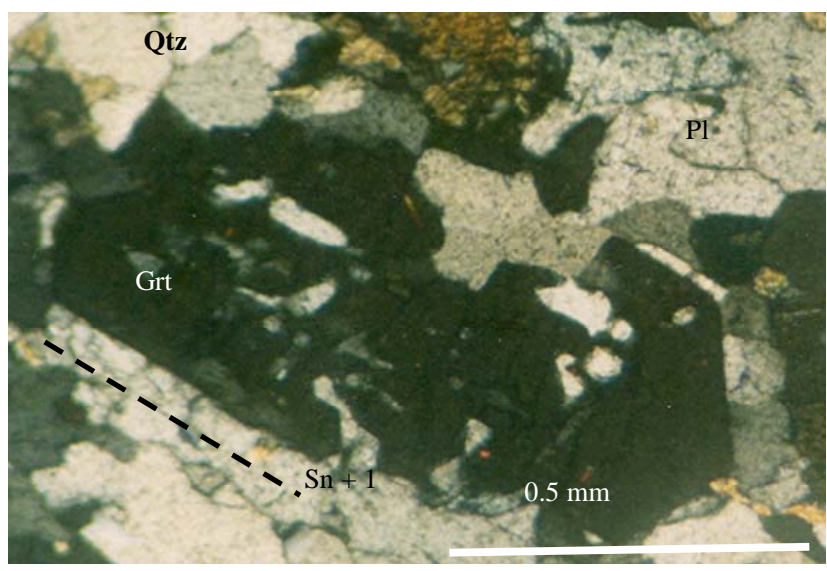

(b2)

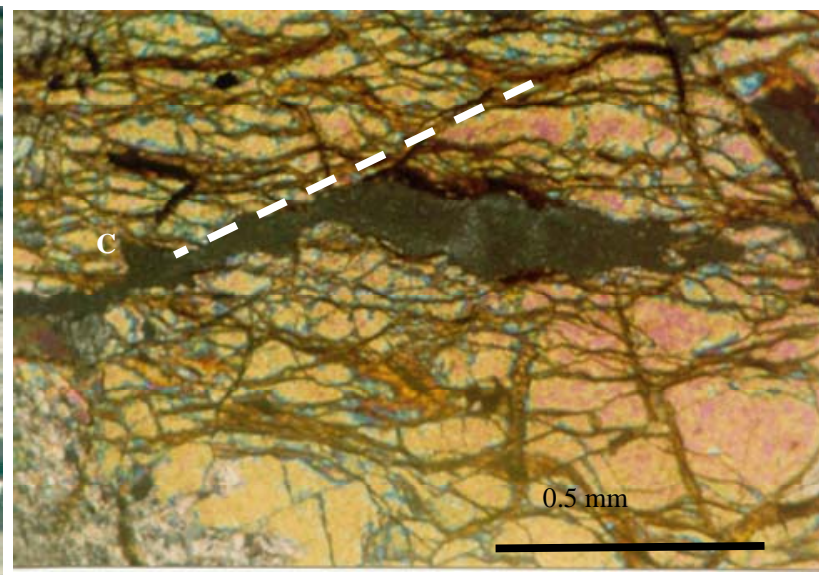

(b4)

Figure 9. (a) Characteristic microstructures of the Lassa-Soumdina leucocratic garnet-bearing granulites (GLS): (a1) Porphyroblastic texture composed of several ante-Dn garnet porphyroblasts surrounded by the main Sn + 1 foliation; (a2) Hypersthène- and diopside-bearing pyroxenic lenses transposed into the $\mathrm{Sn}+1$ foliation; (a3) Detail of a hypersthene porphyroblast surrounded by the $S n+1$ foliation and with a recrystallization rim made up of green hornblende; (a4) Microstructure of an epidote metaplagioclasic granulite, with a plagioclase porphyroblast showing flexural polysynthetic twins and undulatory extinction. (b) Characteristic microstructures of the Lassa-Soumdina leucocratic garnet-bearing granulites (GLS) and associated rocks: (b1) A syn-Dn +1 garnet porphyroblast with a post-Dn +1 rim; (b2) A post-Dn +1 and subautomorphic garnet porphyroblast with quartz inclusions defining $\mathrm{Si}=\mathrm{Se}=\mathrm{Sn}+1$; (b3) Microstructure of kyanite-bearing gneiss showing ante-Dn + 1 kyanite porphyroblasts, with high cleavage deformation and undulatory extinction; (b4) Texture of mylonitic pyroxenite, with porphyroblasts broken up into sub-grains. 
tinguish the syn-Dn garnet sections (sometimes coronitic) from the post-Dn or ante-Dn +1 ones. The latter usually display a broad internal schistosity materialized by synDn quartz inclusions. The second generation of garnet is represented by the syn-Dn +1 type, xenomorphic, helicitic porphyroblasts, and sometimes coronitic (Figure 9 (b1)). Finally, the post-Dn +1 garnet porphyroblasts (Figure 9(b2)), unlike those of the previous generations, are subautomorphic and sometimes display aligned inclusions $(\mathrm{Si}=\mathrm{Se}=\mathrm{Sn}+1)$.

In the leucocratic garnet-bearing granulites, ilmenite occurs quite frequently as xenomorphic clusters or opaque inclusions of ante- or syn-Dn +1 garnet porphyroblasts.

Zircon and rutile crystals and pseudomorphic minerals (sphene, biotite, actinolite, magnetite, epidote, chlorite) can also be seen in the leucocratic granulites.

Kyanite- and garnet-bearing gneisses display microfabrics comparable to those in the leucocratic granulites. More or less elongated or stretched syn-Dn kyanite porphyroblasts define the $S n / / S n+1$ foliation, with strong cleavage deformation and abnormal extinction (Figure 9(b3)). Some kyanite sections clearly appear as syn-Dn + 1 crystals. These two kyanite generations are comparable to those described in the Taneka (TQ) or Badagba group quartzites [11,41]. These gneisses include rare biotite and many accessory minerals: rutile, ilmenite, small sheaves and clusters of white mica surrounding kyanite and chlorite resulted from a partial pseudomorphosis of garnet.

The pyroxenites associated with the leucocratic granulites display granoblastic and quite equant textures. They are made up of variable proportions of orthopyroxenes (hypersthene + enstatite) and clinopyroxenes (augite + diopside) displaying deformed cleavages. Therefore, they can be defined as clino-ortho- or ortho-clinopyroxenites. Their mylonitic equivalents include sigmoidal grains of particularly brecciated pyroxene crystals and microplanes materializing overthrusting or shearing (Figure 9(b4)).

The amphibolites observed in the western Kabye Massif thrust sole generally display a nematogranoblastic texture. Their accicular green hornblende sections determine a $\mathrm{Sn}+1$ foliation. Sometimes, they are porphyroblastic, with syn-Dn quartz inclusions embodying an internal $\mathrm{Si}$ $=$ Sn schistosity. The ante-Dn +1 plagioclase porphyroblasts in these amphibolites appear often epidotized. Subautomorphic actinolite sections are quite abundant in the amphibole-schist where they are sometimes mimetic of the $S n+1$ foliation. In places, actinolite crystals define a rough $\mathrm{Sn}+2$ foliation or constitute post-tectonic clusters that compose actinolite schists. In these amphibolites, ante-Dn +1 garnet porphyroblasts, with syn-Dn quartz inclusions, are surrounded by $\mathrm{Sn}+1$ foliation. Post-Dn + 1 to $\mathrm{Dn}+2$ garnet is represented by small subautomorphic crystals, static on Sn +1 . Large biotite clusters, static on the $\mathrm{Sn}+1$ foliation and typically post-Dn +1 , post-Dn +1 automorphic sphene sections, syn- to postDn +2 epidote, chlorite in more or less oriented clusters or pseudomorphic syn- to post-Dn +2 sheaf-like structures, and magnetite represent the accessory components of these amphibolites.

The Sn, $\mathrm{Sn}+1$ and $\mathrm{Sn}+2$ foliation planes express the Pan-African tectogenesis in the leucocratic and garnet-bearing granulites and their associated rocks. The Sn foliation and syn-Dn mineral paragenesis are clearly transposed into the main Sn +1 foliation. A significant felsic (quartzo-feldpathic) and green hornblende recrystallization defines this slightly folded foliation that surrounds the ante-Dn +1 porphyroblasts. The $\mathrm{C}$ dextral shear plane, described in the mylonitic corridors, especially in the ZMP, probably embodies the Pan-African Dn +2 stage. This tectogenesis remains difficult to retrace in the pyroxenites which display very few planar markers. The Sn +1 foliation, underlined by green hornblende sections, has completely obliterated the Sn foliation in the amphibolites that more clearly display $\mathrm{Pn}+2$ microfolds and sometimes a rough $\mathrm{Sn}+2$ foliation.

Summarizing the different crystalline phases as a function of their relationships with planar structures (Sn, Sn + 1 and $\mathrm{Sn}+2$ ), one can reconstitute the successive parageneses that resulted from the tectono-metamorphic evolution of the western rock suites (GLS) in the Kabye Massif (Table 2), during the Pan-African events.

The parageneses $\mathrm{Cpx}+\mathrm{Opx}+\mathrm{Pl}+\mathrm{Qtz}+\mathrm{Ilm}+\mathrm{Grt}$, observed in the granulites, and Qzt $+\mathrm{Pl}+\mathrm{Ky}+\mathrm{Grt}$, in the kyanite-bearing gneisses, correspond to a granulite facies metamorphism and the Dn deformation stage. In some leucocratic granulites of the western Kabye Massif nappes, the syn-Dn paragenesis postdates the Cpx + Opx $\pm \mathrm{Pl}$ assemblage considered as coeval with a similar assemblage that is particularly frequent in the Kpaza melanocratic granulites (GKM). This ante-Dn assemblage is the main component of the pyroxenic and plagioclasic metacumulates. It corresponds to a relict and ante-metamorphic mineral association of primary magmatic protoliths or the result of an ante- to syn-Dn pre granulitization metamorphism. According to [2], such a paragenesis could be indicative of an ante-collisional eclogitization, dated at around $640 \pm 12 \mathrm{Ma}$ [42] and followed by a syn-Dn granulitization toward $612.5 \pm 0.8$ Ma.

The development of the regional $\mathrm{Sn}+1$ foliation is coeval with the retrograde amphibolitization of the granulites. This syn-Dn +1 retromorphism is represented by characteristic parageneses such as $\mathrm{Hbl}+\mathrm{Pl}+\mathrm{Grt}+\mathrm{Qtz}$, in the granulites, and Qtz + Pl + Grt + Ky, in the gneisses. The retromorphism continued down to the greenschist facies due to the $\mathrm{Dn}+2$ folding phase. The post-tectonic or post-Dn +1 paragenesis Grt $+\mathrm{Bt}+\mathrm{Sph}+\mathrm{Act}+\mathrm{Ep}+$ Mag + Chl, particularly well developed in the amphibo- 
Table 2. Synthesis of crystallization-deformation relationships and characteristic parageneses of the tectono-metamorphic evolution of the Lassa-Soumdina leucocratic granulites (GLS) and associated rocks.

\begin{tabular}{|c|c|c|c|c|c|c|c|}
\hline Deformation & & Dn & & $\mathrm{Dn}+1$ & & $\mathrm{Dn}+2$ & \\
\hline Marks & & Sn & & $\mathrm{Sn}+1$ & & $n+2 / C / S n+$ & \\
\hline Minerals Stages & Ante-Dn & Syn-Dn & Post-Dn Ante-Dn + 1 & Syn-Dn +1 & Post-Dn + 1-Ante-Dn + 2 & Syn-Dn + 2 & Post-Dn +2 \\
\hline Qtz & & $\operatorname{xxxxxxxx}$ & & $\operatorname{xxxxxxxx}$ & & & \\
\hline $\mathrm{Pl}$ & $\operatorname{xxxxx}$ & $\operatorname{xxxxxxxx}$ & & $\operatorname{xxxxxxxx}$ & & & \\
\hline Opx + Cpx & $\operatorname{xxxxx}$ & $\operatorname{xxxxxxxx}$ & & & & & \\
\hline $\mathrm{Hbl}$ & & & & $\operatorname{xxxxxxxx}$ & & & \\
\hline Grt & & $\operatorname{xxxxxxxx}$ & $\operatorname{xxxxxxxx}$ & $\operatorname{xxxxxxxx}$ & $\operatorname{xxxxxxxx}$ & & $\operatorname{xxxxxxxx}$ \\
\hline Ilm & & $\operatorname{xxxxxxxx}$ & & & & & \\
\hline Ky & & $\operatorname{xxxxxxxx}$ & & $\operatorname{xxxxxxxx}$ & & & \\
\hline $\mathrm{Bt}$ & & & & & & $\operatorname{xxxxxxx}$ & $\operatorname{xxxxxxxx}$ \\
\hline Sph & & & & & & & $\operatorname{xxxxxxxx}$ \\
\hline Act & & & & & & $\operatorname{xxxxxxx}$ & $\operatorname{xxxxxxxx}$ \\
\hline Ep & & & & & & $\operatorname{xxxxxxx}$ & $\operatorname{xxxxxxxx}$ \\
\hline Mag & & & & & & & $\operatorname{xxxxxxxx}$ \\
\hline Chl & & & & & & $\mathrm{xxx}$ & $\operatorname{xxxxxxxx}$ \\
\hline Metamorphism & & \multicolumn{2}{|c|}{ Granulite facies } & \multicolumn{2}{|c|}{ Amphibolite facies } & \multicolumn{2}{|c|}{ Greenschist facies } \\
\hline
\end{tabular}

lites, characterizes this last retromorphic stage.

In summary, the tectono-metamorphic evolution of the leucocratic granulites (GLS) is comparable to that of the melanocratic granulites (GKS and GKM). It consists of a possible ante-Dn eclogitization at about $640 \pm 12 \mathrm{Ma}$, a syn-Dn granulitization at about $612 \pm 0.8 \mathrm{Ma}$, and a two stage widespread retromorphism resulted in a syn-Dn +1 amphibolite facies followed by a syn- to post-Dn +2 greenschist facies.

\section{Synthesis and Conclusion}

The Kabye and Kpaza Massifs correspond to major granulitic nappe piles of the Pan-African Dahomeyide suture zone in northern Togo. They fit into the organization of the lithostructural units attributed to the Pan-African tangential and fold tectonics. Thus, their relationships with the external and internal zone units are overthrusting in nature (Figures 2, 3 and 7): the Kabye Massif granulitic nappes are thrust over the Kara-Niamtougou orthogneissic unit (UKN) belonging to the external zone; those Kabye Massif nappes underlie the internal zone nappes, represented especially by the Binah and Mono Complexes (CB and CM) and the Dompago orthogneissic unit (UOD). The Kpaza Massif is tectonically enclosed between the CM nappes and the Sokode- Kemeni unit (USK).

The Kabye Massif consists of two major petrographic suites constituting its western nappe unit, made up of leucocratic garnet-bearing granulites (GLS), and eastern nappe unit comprising melanocratic granulites with metagabbroic features (GKS). Geochemical data lead to infer that the entire granulite suite of the Kabye Massif corresponds to a tectonically overturned oceanic arc magmatic sequence [8]. The Kpaza Massif comprises only two nappes whose petrographic components (GKM) are comparable to those of the eastern Kabye Massif nappe unit.

Mineral parageneses and the analysis of microstructures define three major and very distinct tectonic phases (Dn, Dn +1 and $\mathrm{Dn}+2$ ), coeval with three metamorphic recristallization stages. Three generations of planar structures (Sn, Sn +1 and $S n+2 / C$ ) resulted from this Pan-African tectogenesis. The mineral components of the granulites and their associated rocks have been determined as ante-Dn, syn-Dn, syn-Dn +1 and syn- to postDn +2 parageneses (Table 3). The ante-Dn parageneses consist of porphyroblasts that appear to predate the $\mathrm{Sn}$ plane. They are very evident in the Kpaza Massif granulites (GKM) and especially in the pyroxenic or feldspathic metacumulates. They represent relicts of an anteDn recristallization. In the Kabye Massif granulites, these ante-Dn paragenesis $(\mathrm{Opx}+\mathrm{Cpx}+\mathrm{Pl})$ could represent a magmatic crystallization at $\mathrm{P}<8 \mathrm{kbar}$ and $\mathrm{T}>800^{\circ} \mathrm{C}$ [43]. It could also indicate an ante-collisional eclogitization dated at around $640 \mathrm{Ma}$ [2]. Therefore, the syn-Dn parageneses postdate mineral associations due to magmatic protoliths or those resulted from an ante-Dn metamor- 
Table 3. Synthesis of the parageneses characterizing the tectono-metamorphic evolution of the Kabye and Kpaza Massifs granulites and associated rocks.

\begin{tabular}{|c|c|c|c|c|c|}
\hline \multirow{2}{*}{ Litho-structural suites } & \multirow{2}{*}{ Petrographic components - } & \multicolumn{4}{|c|}{ Parageneses } \\
\hline & & Ante-Dn & Syn-Dn & Syn-Dn + 1 & Syn to post-Dn +2 \\
\hline \multirow{5}{*}{$\begin{array}{l}\text { Lassa-Soumdina } \\
\text { Granulites (GLS) }\end{array}$} & $\begin{array}{l}\text { Leucocratic garnet-bearing } \\
\text { granulites }\end{array}$ & $\mathrm{Opx}+\mathrm{Cpx}+\mathrm{Pl}$ & $\begin{array}{c}\text { Opx }+\mathrm{Cpx}+\mathrm{P} \\
+\mathrm{Grt}+\mathrm{Qtz}+\mathrm{Ilm}\end{array}$ & $\mathrm{Hbl}+\mathrm{Pl}+\mathrm{Qtz}+\mathrm{Grt}$ & $\begin{array}{c}\mathrm{Qtz}+\mathrm{Grt}+\mathrm{Sph}+\mathrm{Ep}+\mathrm{Bt} \\
\quad+\mathrm{Chl}+\mathrm{Act}+\mathrm{Mag}\end{array}$ \\
\hline & Pyroxenites & $\mathrm{Opx}+\mathrm{Cpx} \pm \mathrm{Pl}$ & $\mathrm{Opx}+\mathrm{Cpx}+\mathrm{Pl}+\mathrm{Grt}$ & $\mathrm{Hbl}+\mathrm{Pl}+\mathrm{Grt}$ & Act + Chl + Tlc + Serp \\
\hline & $\begin{array}{c}\text { Kyanite- and } \\
\text { garnet-bearing gneisses }\end{array}$ & & $\begin{array}{l}\mathrm{Ky}+\mathrm{Qtz}+\mathrm{Pl} \\
+\mathrm{Grt}+\mathrm{Ilm}\end{array}$ & $\mathrm{Qtz}+\mathrm{Pl}+\mathrm{Grt}+\mathrm{Ky}$ & $\mathrm{Qtz}+\mathrm{Bt}+\mathrm{Ms}$ \\
\hline & Amphibolites & & $\mathrm{Opx}+\mathrm{Pl}+\mathrm{Qtz}$ & $\mathrm{Hbl}+\mathrm{Pl}+\mathrm{Qtz}+\mathrm{Grt}$ & $\begin{array}{c}\mathrm{Qtz}+\mathrm{Grt}+\mathrm{Sph}+\mathrm{Ep}+\mathrm{Bt} \\
\quad+\mathrm{Chl}+\mathrm{Act}+\mathrm{Mag}\end{array}$ \\
\hline & Melanocratic granulites & $\mathrm{Opx}+\mathrm{Cpx}+\mathrm{Pl}$ & $\begin{array}{l}\mathrm{Opx}+\mathrm{Cpx}+\mathrm{Pl} \\
+\mathrm{Qtz}+\mathrm{Ilm}\end{array}$ & $\mathrm{Hbl}+\mathrm{Pl}+\mathrm{Qtz}+\mathrm{Grt}$ & $\begin{array}{l}\mathrm{Qtz}+\mathrm{Grt}+\mathrm{Ep}+\mathrm{Bt} \\
+\mathrm{Chl}+\mathrm{Act}+\mathrm{Mag}\end{array}$ \\
\hline \multirow[t]{2}{*}{$\begin{array}{c}\text { Ketao-Sirka } \\
\text { Granulites (GKS) }\end{array}$} & Pyroxenites & $\mathrm{Opx}+\mathrm{Cpx} \pm \mathrm{Pl}$ & $\mathrm{Opx}+\mathrm{Cpx}+\mathrm{Pl}$ & $\mathrm{Hbl}+\mathrm{Pl}$ & Act + Chl + Serp + Tlc \\
\hline & Melanocratic granulites & $\mathrm{Cpx}+\mathrm{Opx}+\mathrm{Pl}$ & $\begin{array}{c}\mathrm{Opx}+\mathrm{Cpx}+\mathrm{Pl} \\
+\mathrm{Ilm} \pm \mathrm{Qtz} \pm \mathrm{Grt}\end{array}$ & $\mathrm{Hbl}+\mathrm{Pl} \pm \mathrm{Qtz} \pm \mathrm{Grt}$ & $\mathrm{Bt}+\mathrm{Sph}$ \\
\hline \multirow[t]{2}{*}{$\begin{array}{c}\text { Kpaza Massif } \\
\text { Granulites (GKM) }\end{array}$} & Pyroxenites & $\mathrm{Cpx}+\mathrm{Opx} \pm \mathrm{Pl}$ & $\mathrm{Opx}+\mathrm{Cpx}+\mathrm{Pl} \pm \mathrm{Grt}$ & $\mathrm{Hbl}+\mathrm{Pl} \pm \mathrm{Grt}$ & Act + Chl + Serp + Tlc \\
\hline & Amphibolites & & $\mathrm{Opx}+\mathrm{Pl}$ & $\mathrm{Hbl}+\mathrm{Pl} \pm \mathrm{Qtz}$ & $\begin{array}{c}\mathrm{Grt}+\mathrm{Ep}+\mathrm{Bt}+\mathrm{Chl} \\
+\mathrm{Act}+\mathrm{Mag}\end{array}$ \\
\hline \multicolumn{2}{|c|}{ Metamorphism } & Eclogite facies? & Granulite facies & Amphibolite facies & Greenschist facies \\
\hline
\end{tabular}

phic recrystallization. They correspond to a metamorphic peak defined by Opx $+\mathrm{Cpx}+\mathrm{Pl}+\mathrm{Qzt}+\mathrm{Grt}+\mathrm{Ilm}+\mathrm{Rt}$ (in the granulites) and Qzt $+\mathrm{Pl}+\mathrm{Ky}+\mathrm{Grt}+\mathrm{Ilm}$ (in the gneisses). Such syn-Dn parageneses characterize a granulitization at $\mathrm{P}=19 \pm 1 \mathrm{kbar}$ and $\mathrm{T}>900^{\circ} \mathrm{C} \pm 100^{\circ} \mathrm{C}$ [42], during the Pan-African collision episode in the Dahomeyide orogenic belt, at around $612 \mathrm{Ma}$ [2]. According to [8], granulitization in the Kabye Massif would be represented by the parageneses $\mathrm{Grt}+\mathrm{Cpx}+\mathrm{Pl} \pm \mathrm{Opx}$ and $\mathrm{Opx}+\mathrm{Cpx}+\mathrm{Pl}$ indicating an initial metamorphism at 9 kbar and $900^{\circ} \mathrm{C}$. This one would be followed by a metamorphic peak at $18 \pm 3 \mathrm{kbar}$ and $850^{\circ} \mathrm{C} \pm 20^{\circ} \mathrm{C}$ in the frontal part of the western nappes (GLS), or at $12 \pm 2$ kbar and $775^{\circ} \mathrm{C} \pm 15^{\circ} \mathrm{C}$ in the eastern nappes (GKS). According to [44], the syn-collisional granulitization occurred at 615 - $613 \mathrm{Ma}$ in the Pan-African suture zone. It was accompanied by a lithospheric extension during which alkaline intrusions resulted (594 - $592 \mathrm{Ma}$ ).

These syn-Dn granulites underwent two retromorphic episodes. The syn-Dn +1 retrometamorphism deeply reworked the granulites and led to an amphibolite facies represented by the parageneses $\mathrm{Hbl}+\mathrm{Pl}+\mathrm{Qtz}+\mathrm{Grt}$ (in the granulites) and $\mathrm{Qtz}+\mathrm{Pl}+\mathrm{Grt}+\mathrm{Ky}$ (in the gneisses). This retrograde transformation probably corresponds to a progressive hydration episode of the granulites at $700^{\circ} \mathrm{C}$ $800^{\circ} \mathrm{C}$ and $8-10 \mathrm{kbar}$ or $630^{\circ} \mathrm{C}$ and $8 \mathrm{kbar}$ [18]. Such a cooling phenomenon could be related to the emplacement of nappes during the syn-Dn +1 tangential or obduction phase of the Pan-African orogeny $[8,11,18,19$,
34]. This first retrograde metamophism of the granulites occurred around $587 \pm 4.3$ to $582 \pm 2 \mathrm{Ma}\left({ }^{40} \mathrm{Ar} /{ }^{39} \mathrm{Ar}\right.$ hornblende age; [9]) and probably coincided with the blastomylonitization of the Lato eclogites toward $580 \mathrm{Ma}$ [42] or with the amphibolitization of the Akuse/Shai Massif granulites between 590 and $570 \mathrm{Ma}(\mathrm{U} / \mathrm{Pb}$ zircon age; [15]).

The second retrograde metamophism is defined by parageneses of greenschist facies associated with the Dn + 2 folding phase, locally characterized by a dextral shear regime. It corresponds to the last Pan-African metamorphic recrystallization in the Kabye and Kpaza Massifs. According to [9], this last major tectono-metamorphic event, considered as coeval with the syn-Dn +2 folding and shearing phase, probably occurred at about $566 \mathrm{Ma}$ in the Akuse/Shai Massif granulites $\left({ }^{40} \mathrm{Ar} /{ }^{39} \mathrm{Ar}\right.$ hornblende age). This age is comparable to the $\mathrm{K} / \mathrm{Ar}(572 \pm 15 \mathrm{Ma})$ and $\mathrm{Rb} / \mathrm{Sr}(545 \pm 11 \mathrm{Ma}$ ) ages yielded by biotite in metasyenites from the Kpong Complex belonging to this massif [45]. Moreover, it is not very different from the ages (566 - $535 \mathrm{Ma}$ ) attributed to the last major shearing phase in the Adrar des Iforas [46].

The polyphase evolution of the Kabye and Kpaza massifs integrate the recent Rb-Sr, Sm-Nd and zircon U-Pb ages obtained on migmatites and granitoid rocks from Dahomeyide internal zone in Togo and Benin [31]. Indeed, these ages locate the whole migmatization and granite formation between 660 - 550 Ma during the PanAfrican event. 
The present micro- and petrostructural analyses integrate the geochronological and thermobarometric data available on the Kabye Massif granulites or on the entire Pan-African suture zone in the Dahomeyide orogen. Reconstituting the successive parageneses related to the different tectonic phases recorded in the various rocks studied, the present paper confirms the involment of the Kabye and Kpaza Massifs in the complex process of the Pan-African continental collision in this orogen.

\section{REFERENCES}

[1] P. Affaton, M. A. Rahaman, R. Trompette and J. Sougy, "The Dahomeyide Orogen: Tectonothermal Evolution and Relationships with the Volta Basin,” In: Dallmayer and Lécorché, Ed., The West-African Orogen and Circum Atlantic Correlatives, 1CGP, IUGS, UNESCO, 1991, pp. 107-122.

[2] P. Affaton, A. Kröner and K. F. Seddoh, "Pan African Granulites Formation in the Kabye of Northern Togo (West Africa): Pb-Pb Zircon Ages,” International Journal of Earth Sciences, Vol. 88, No. 4, 2000, pp. 778-790. doi:10.1007/s005310050305

[3] B. Péré and F. Colin, "The Chromite Deposit of Farande (Lama-Kara District, Togo),” Annals of Sciences Institute, Université du Bénin, Togo, 1972, pp. 1-23.

[4] I. R. Breda, "Study of the Geological Cartography and Recognition Mining Prospection in the North of Latitude 11 North (Benin),” Final Report, Project No. 4105-01113-20, Geominerarialtuliona, Borgo S. Dalmazzo, 1982.

[5] Y. Noël, N. B. Péré, A. Aregba, T. L. Lawson and K. S. Godonou, "Explicative Notice of the Geological Map (Scale: 1/200,000), Kara Sheet,” DGMG-Lomé/BRGM, Orléans, 1984.

[6] P. Affaton, "The Volta Basin (West Africa): An Upper Proterozoic Passive Margin Tectonized at the Pan-African (600 \pm 50 Ma),” Collection Etudes \& Theses, Paris, 1990.

[7] B. E. Sabi, "Characterization of the Pan-African Dahomeyide Belt Segment in Togo at Pagouda Latitude,” DEA Dissertation, Check Anta Diop University, Dakar, 1992.

[8] G. Duclaux, R. P.Ménot, S. Guillot, Y. Agbossoumondé and N. Hilaret, “The Mafic Complex of the Kabyé Massif (North Togo and North Benin): Evidence of a Pan-African Granulitic Continental arc Root," Precambrian Research, Vol. 151, No. 1-2, 2006, pp. 101-118. doi:10.1016/j.precamres.2006.08.012

[9] K. Attoh, R. D. Dallmeyer and P. Affaton, “Chronology of Nappe Assembly in the Pan-Africa Dahomeyide Orogen, West Africa: Evidence from ${ }^{40} \mathrm{Ar} /{ }^{39} \mathrm{Ar}$ Mineral Ages," Precambrian Research, Vol. 82, No. 1, 1997, pp. 153-171. doi:10.1016/S0301-9268(96)00031-9

[10] N. Hilaret, "Le Massif Granulitique HP de Kabyé (NordTogo), Témoin d'un arc Continental Impliqué dans l’Orogenèse Panafricaine,” Mémoire DEA, Université J. Monnet St-Etienne, St-Etienne, 2004.

[11] M. S. Tairou, "La Tectonique Tangentielle Panafricaine au Nord-Togo,” Ph.D. Dissertation, Université de Lomé,
Lomé, 2006.

[12] B. E. Sabi, "Etude Pétrologique et Structurale du Massif Kabyè, Nord-Togo,” Ph.D. Dissertation, Université de Lomé, Lomé, 2007.

[13] R. P. Ménot and K. F. Seddoh, "The Eclogites of Lato Hills (South Togo, West Africa): Relies from Early Tectonometamorphic Evolution of the Pan-African Orogeny," Chemical Geology, Vol. 50, No. 1-3, 1985, pp. 313-330. doi:10.1016/0009-2541(85)90126-3

[14] K. Attoh, "Dahomeyides in Southern Ghana: Evidence for Oceanic Closure and Crustal Imbrication in a PanAfrican Orogen," Mémoire CIFEG, Vol. 22, 1990, pp. 159-164.

[15] K. Attoh, "High-Pressure Granulite Facies Metamorphism in the Pan-African Dahomeyide Orogen, West Africa," Journal of Geology, Vol. 106, No. 2, 1998, pp. 236-246. doi:10.1086/516019

[16] K. Attoh, G. S. A. Hawkings and S. A. Bowring, "U-Pb Zircon Ages from the Pan-African Dahomeyide Orogen, West Africa," EOS Transactions on American Geophysical Union Spring Meeting, Vol. 72, 1991.

[17] Y. Agbossoumondé, "The Ultrabasic Complexes of the Pan-African Belt in Togo (Agou-Atakpame Axis, South Togo) Petrologic, Mineralogical and Geochemical Study," Ph.D. Dissertation, Université Jean Monnet, St. Etienne, 1998.

[18] Y. Agbossoumondé, R.-P. Ménot and S. Guillot, "Metamorphic Evolution of Neoproterozoic Eclogites from South Togo (West Africa),” Journal of African Earth Sciences, Vol. 33, No. 2, 2001, pp. 227-244. doi:10.1016/S0899-5362(01)80061-0

[19] Y. Agbossoumondé, S. Guillot and R.-P. Ménot, "PanAfrican Subduction-Collision Envent Evidence by High-P Coronas in Metanorites from the Agou Massif (Southern Togo),” Precambrian Research, Vol. 135, No. 1-2, 2004, pp. 1-21. doi:10.1016/j.precamres.2004.06.005

[20] K. Attoh and J. Morgan, “Geochemistry of High-Pressure Granulites from the Pan-African Dahomeyide Orogen, West Africa: Constraints on the Origin and Composition of Lower Crust,” Journal of African Earth Sciences, Vol. 39, No. 3-5, 2004, pp. 201-208. doi:10.1016/j.jafrearsci.2004.07.048

[21] K. Attoh and P. M. Nude, “Tectonic Significance of Carbonatites and Ultrahigh-Pressure Rocks in the Pan-African Dahomeyide Suture Zone, Southeastern Ghana,” In: N. Ennih and J.-P. Liégeois, Eds., The Boundaries of the West African Craton, Geological Society London, Special Publications, Vol. 297, 2008, pp. 217-231.

[22] R. Trompette, "Les Dahomeyides au Bénin, Togo et Ghana: une Chaîne de Collision d'âge Panafricain,” Revue Géologie Dynamique et Géographie Physique, Vol. 21, No. 5, 1979, pp. 339-349.

[23] R. Trompette, “The Pan-African Dahomeyide Belt and the Volta Basin (South-Eastern Margin of the West African Craton),” Mémoire BRGM, Vol. 92, 1980, pp. 9-62.

[24] P. Affaton, J. Sougy and R. Trompette, "The TectonoStratigraphic Relationships between the Upper Precambrian and Lower Paleozoic Volta Basin and the Pan-Af- 
rican Dahomeyide Orogenic Belt (West Africa)," American Journal Sciences, Vol. 280, 1980, pp. 224-248. doi:10.2475/ajs.280.3.224

[25] N. Simpara, J. Sougy and R. Trompette, "Lithostratigraphy and Structure of the Buem, External Unit of Pan-African Dahomeyide Belt in the Bassar Region (Togo)," Journal of African Earth Sciences, Vol. 3, No. 4, 1985, pp. 479-486.

[26] Y. Agbossoumondé, R.-P. Ménot, J. L. Paquette, S. Guillot, S. Yessoufou and C. Perrache, "Petrological and Geochronological Constraints on the Origin of the PaliméAmlamé Granitoids (South Togo, West Africa): A Segment of the West African Craton Paleoproterozoic Margin Reactivated during the Pan African Collision," Gondwana Research, Vol. 12, No. 4, 2007, pp. 476-488. doi:10.1016/j.gr.2007.01.004

[27] M. S. Tairou, P. Affaton, B. E. Sabi and K. F. Seddoh, "Tectono-Metamorphic Evolution of the Mo and KaraNiamtougou Orthogneissic Suites, Northern Togo," Global Journal of Geological Sciences, Vol. 7, No. 2, 2009, pp. 93-100.

[28] R. Caby and J. M. Boesse, "Pan-African Nappe System in Southwest Nigeria: The Ife-Ilesha Schist Belt,” Journal of African Earth Sciences, Vol. 33, No. 2, 2001, pp. 211225. doi:10.1016/S0899-5362(01)80060-9

[29] P. Affaton, J. L. Lassere, L. T. Lawson and P. L. Vincent, "Explicative Notice of the Geological Maps (scale: 1/200, 000) of the Togo Republic and Benin Popular Republic between Latitudes 9 and 10 North (Bassari-Djougou and Parakou-Nikki Sheets),” Rapport BNRM-Togo, BRGMFrance et OBEMINES-Bénin, 1978.

[30] J. P. Sylvain, J. Collart, A. Aregba and S. Godonou, “Explicative Notice of the Geological Map (Scale: 1/500,000) of Togo,” Mémoire DGMG/BNRM, Lomé, 1986.

[31] F. Kalsbeek, P. Affaton, B. Ekwueme, R. Frei and K. Thrane, "Geochronology of Granitoid and Metasedimentary Rocks from Togo and Benin, West Africa: Comparisons with NE Brazil," Precambrian Research, Vol. 196-197, 2012, pp. 218-233. doi:10.1016/j.precamres.2011.12.006

[32] M. S. Tairou, P. Affaton, J.-P. Gélard, R. Aïte and B. E. Sabi, "Panafrican Brittle Deformation and Paleostress Superposition in Northern Togo (West Africa)," Comptes Rendus Géosciences, Vol. 339, 2007, pp. 849-857.

[33] R. Caby, "Precambrian Terranes of Benin-Nigeria and Northeast Brazil and the Late Protererozoic South Atlantic Fit," Geological Society of America, Special Paper, Vol. 230, 1989, pp. 145-158.
[34] C. Castaing, C. Triboulet, J. L. Feybesse and P. Chevremont, "Tectono-Metamorphic Evolution of Ghana, Togo, and Benin in the Light of the Pan-African/Brasiliano Orogeny," Tectonophysics, Vol. 218, No. 4, 1993, pp. 323342. doi:10.1016/0040-1951(93)90322-B

[35] P. Affaton, J. P. Gélard and N. Simpara, "Paleostresses Recorded by Fracturing in the Atacora Structural Unit (Pan-African Dahomeyide Belt, Togo)," Comptes Rendus Académie des Sciences, Vol. 312, 1991, pp. 763-768.

[36] A. Spry, “Metamorphic Textures,” Pergamon Press, Oxford, 1969.

[37] A. Nicolas, “Principes de Tectonique,” 2nd Edition, Masson, Paris, 1988.

[38] J. P. Bard, "Microtextures des Roches Magmatiques et Métamorphiques,” 2nd Edition, Masson, Paris, 1990.

[39] C. W. Passchier and R. A. J. Trouw, "Micro-Tectonics," Springer, Amsterdam, 1995.

[40] R. Kretz, "Symbols of Rock-Forming Minerals,” American Mineralogist, Vol. 68, 1983, pp. 277-279.

[41] S. Alidou, P. Germain, J.-L. Julien and P. Tempier, "On the Metamorphism of the Badagba Quartzites Group (Dahomey)," Comptes Rendus Académie des Sciences, Vol. 281, 1975, pp. 339-342.

[42] J. Bernard-Griffiths, J. Jeucat and R. P. Ménot, "Isotopic (Rb-Sr, U-Pb and Sm-Nd) and Trace Element Geochemistry of Eclogites from the Pan-African Belt: A Case Study from REE Fractionation during High-Grade Metamorphism,” Lithos, Vol. 27, No. 1, 1991, pp. 43-57. doi:10.1016/0024-4937(91)90019-H

[43] G. Duclaux, S. Guillot, Y. Agbossoumondé, R. P. Ménot and N. Hilaret, "The Kabye Granulitic Massif (Northern Togo), a Witness of Subducted and Collided Intra-Oceanic Pan-African Arc,” 20è colloque de Géologie Africaine, Orléans, 2-7 June 2004.

[44] K. Attoh, F. Corfu and M. P. Nude, "U-Pb Zircon Age of Deformed Carbonatite and Alkaline Rocks in the PanAfrican Dahomeyide Suture Zone, West Africa,” Precambrian Research, Vol. 155, No. 3-4, 2007, pp. 251-260. doi:10.1016/j.precamres.2007.02.003

[45] E.K. Agyei, J.E.J.M. van Landewijk, R.L. Amstrong, L.F. Harakal, K.L. Scott, "Rb-Sr and K-Ar Geochronometry of Southeastern Ghana,” Journal of African Earth Sciences, Vol. 6, 1987, pp. 153-161. doi:10.1007/BF00399709

[46] J. R. Lancelot, A. M. Boullier, H. Maluski and J. Ducrot, "Deformation and Related Radiochronology in a Late PanAfrican Mylonitic Shear Zone, Adrar des Iforas (Mali)," Contrib Mineral Petrology, Vol. 82, 1983, pp. 312-326. 